\title{
FEDERALISMO, MUNICÍPIOS E DECISÕES LEGISLATIVAS: A CRIAÇÃO DE MUNICÍPIOS NO RIO GRANDE DO SUL
}

\author{
Fabrício Ricardo de Limas Tomio
}

\begin{abstract}
RESUMO
Este artigo aborda o processo político que gerou os milhares de novos municípios no Brasil, utilizando o estado do Rio Grande do Sul como cenário das relações entre os poderes Executivo e Legislativo estaduais a partir da segunda metade do século XX. A recente fragmentação das unidades de governo local, assim como a institucionalização de uma federação em três níveis, é um fenômeno político restrito ao Brasil. Entre os estados, o Rio Grande do Sul foi aquele que mais intensamente fragmentou seu território: entre os anos de 1988 e 2000 foram criados 253 novos municípios nesse estado. Para descrever esse processo utilizarei uma abordagem histórico-institucional. As decisões favoráveis à criação e municípios predominaram no processo decisório estadual: 1) porque a consolidação da descentralização fiscal garantiu a estabilidade das transferências fiscais aos municípios; 2) devido à descentralização da regulamentação dos novos municípios em favor dos estados e 3) porque os poderes legislativos estaduais conquistaram grande autonomia no processo decisório da criação de municípios, como no Rio Grande do Sul, onde a participação popular na proposição legislativa, a prerrogativa exclusiva dos eleitores iniciarem a tramitação do processo e a manifestação popular no plebiscito limitaram a capacidade de controle do poder Executivo sobre o resultado legislativo.
\end{abstract}

PALAVRAS-CHAVE: federalismo; poder Legislativo estadual; novos municípios.

\section{INTRODUÇÃO}

A Constituição Federal de 1988 gerou um novo ordenamento federativo. Os constituintes não só estabeleceram as bases do Estado democrático como também instituíram um novo "pacto federativo”. Em quase todas as constituições (exceto na carta de 1937), os municípios foram definidos como organizações políticas autônomas; contudo, somente a Constituição de 1988 atribuiu uma autonomia plena aos municípios, elevando-os de fato ao status de ente federativo, com prerrogativas invioláveis por qualquer nível mais abrangente de governo. Essa situação peculiar não é identificável em outros países organizados em uma federação. Na maioria das federações os municípios ou outros níveis de poder local são divisões administrativas das unidades federadas, que delegam (ou não) diferentes níveis de autonomia administrativa aos governos locais. $\mathrm{O}$ arranjo federativo brasileiro transformou o país na única federação com três níveis políticos constitucionalmente autônomos: a União, os estados (e o Distrito Federal) e os municípios ${ }^{1}$.

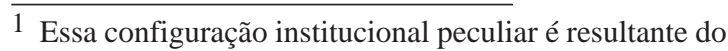

A descentralização política foi acompanhada da ampliação de recursos fiscais e das competências tributárias dos municípios e do mais expressivo processo de fragmentação dos municípios brasileiros - algo que, no período posterior à vigência da Constituição de 1988, originou 1385 novos municípios no Brasil (1/4 de todos municípios existentes atualmente). Essa situação, sem similar recente em outros estados nacionais, despertou preocupações sobre as conseqüências da falta de estabilidade no ordenamento federativo, como o desperdício fiscal e a instabilidade na ges-

texto da última carta constitucional: Art. 1: "A República Federativa do Brasil, formada pela união indissolúvel dos Estados e Municípios e do Distrito Federal, constitui-se em Estado Democrático de Direito [...]” e Art. 18: “A organização político-administrativa da República Federativa do Brasil compreende a União, os Estados, o Distrito Federal e os Municípios, todos autônomos, nos termos desta Constituição" (BRASIL, 1988). Antes de 1988, apesar de a autonomia municipal ser citada nas constituições anteriores, muitos juristas não consideravam a federação brasileira como uma organização política de três graus distintos. Ataliba (1987, p. 73-75), por exemplo, afirmava que, mesmo não sendo hierarquicamente subordinado, o município "não integra a Federação", sendo sua autonomia somente "uma

Rev. Sociol. Polít., Curitiba, 24, p. 123-148, jun. 2005 
tão das políticas públicas ${ }^{2}$. Entretanto, as conseqüências desse processo, sobretudo sobre as relações intergovernamentais e gestão de políticas locais, não são objeto deste texto e merecem uma investigação maior no futuro, sobretudo porque a fragmentação municipal no Brasil é um processo inconcluso e interrompido pela Emenda Constitucional n. 15, de 1996.

forma qualificada de descentralização política”. Já Montoro definia o município brasileiro como uma "entidade estatal rígida" que, a exemplo dos estados-membro de uma federação, possui competências atribuídas pela Constituição Federal, como o poder de império, o poder político e a autonomia administrativa, política e legislativa. Entretanto, não seriam entidades federativas de mesma natureza, porque, diferentemente dos estados, os municípios não possuíam (antes de 1988) poder de auto-organização (Constituição ou Lei Orgânica), não participam da formação da vontade geral (por meio de um órgão legislativo como o Senado Federal) e não possuem poder de dominação própria (órgãos judiciários para a aplicação do Direito municipal) (MONTORO, 1974, p. 105-111). Mesmo caracterizando o município antes da promulgação da Constituição de 1988, esses autores identificaram o alto grau de autonomia municipal, que foi radicalizado na nova carta. Por exemplo, os municípios conquistaram o poder de auto-organização por meio de leis orgânicas votadas pelas câmaras municipais, tal qual as constituições estaduais. Isso só existia anteriormente no Rio Grande do Sul, enquanto delegação de um poder estadual aos municípios (idem, p. 122). Sobre as características institucionais do município no federalismo brasileiro, ver também Castro (1987), Giannini (1990), Mello (1993), Affonso e Silva (1995a; 1995b) e Soares (1998).

2 Para entender a relação entre descentralização e democratização no Brasil são interessantes as seguintes referências: os trabalhos de Arretche (1995; 1996), que abordam a confusão no uso desses termos, polemizando a continua vinculação entre eles na literatura; também, nesse aspecto, são interessantes os trabalhos de Tobar (1991) e Uga (1991); o debate sobre a descentralização fiscal e a fragilidade dos municípios em Gomes e MacDowell (1997); a relação entre cidadania e estruturas de governo local em Fischer (1993) apresenta subsídios sociológicos relevantes ao debate; sobre a heterogeneidade do processo de descentralização das políticas sociais, ver Castro (1991), Arretche (1995; 1998; 1999), Almeida (1995), Medina (1987), Teixeira (1992; 1994) e Baêta (1989); sobre o aumento do poder político dos governantes estaduais, ver Abrúcio e Samuels (1997) e Abrúcio (1998); a respeito da ideologia municipalista, ver Melo (1993) e, sobre a defesa das emancipações municipais como um meio de reforçar a democracia e a descentralização política, são relevantes os trabalhos dos técnicos do Instituto Brasileiro de Administração Municipal (IBAM) e a Fundação Prefeito Faria Lima-Centro de Estudos e Pesquisas de Administração Municipal (Cepam), sobretudo Bremaeker (1991; 1993), Jacobi (1990; 1991) e Mello (1991; 1992).
Este texto concentra-se na contextualização do processo político estadual que gerou as decisões políticas que criaram os milhares de municípios atualmente existentes. Para explorar esse processo decisório, utilizo o estado do Rio Grande do Sul como cenário das relações entre os poderes Executivo e Legislativo estaduais e estendo a descrição até a metade do século XX. Não pretendo generalizar as descrições retiradas da investigação desse caso para as outras unidades federativas, mas penso que essa descrição pode servir de roteiro para estudos similares em outros estados, tornados mais precisos os modelos explicativos sobre o processo decisório estadual que originou os municípios na história recente brasileira.

Entre todos os estados, o Rio Grande do Sul foi aquele que mais intensamente fragmentou seu território. Quase 20\% dos novos municípios brasileiros gerados após 1988 encontram-se nessa unidade da federação. Isto é, para cada cinco emancipações, uma ocorreu em terras gaúchas. Em termos absolutos não há qualquer ocorrência semelhante entre os outros estados. Minas Gerais e Tocantins, os outros estados com maior número de casos de emancipação municipal, geraram aproximadamente a metade dos municípios criados pelo Rio Grande do Sul.

Entre os anos de 1988 e 2000 foram criados 253 novos municípios gaúchos. Dado que nenhum deles foi emancipado após 1996, mais da metade dos municípios que existem atualmente no Rio Grande do Sul originou-se em um período inferior a dez anos e simplesmente não existia antes das transformações institucionais decorrentes da redemocratização brasileira. A retomada emancipacionista ocorreu durante a redemocratização, tomando impulso após a promulgação da Constituição de 1988. Em virtude disso, muitos autores sugeriram que a variação no regime político determinaria o ritmo da criação de municípios devido à descentralização política, institucional e fiscal. Entretanto, esse tipo de explicação, apesar de não totalmente equivocada, é muito genérica e não apresenta os mecanismos políticos e institucionais específicos que determinariam a ocorrência das "ondas" ou "surtos" emancipacionistas ${ }^{3}$. O processo emancipacionista

3 Esse tipo de explicação, que define o regime político como variável independente da intensidade de emancipações municipais, está presente na literatura e tem sua melhor construção e argumentação desenvolvida por Gomes e 
recente não é resultado direto do regime político, mas de fatores políticos e institucionais mais específicos.

O mesmo contexto institucional geral moldou o ambiente de decisão política que predispôs a criação de novos municípios a partir da década de 1980 em todo o Brasil. Esse contexto caracterizou-se pela ampliação dos recursos fiscais transferidos aos municípios, pela descentralização da regulamentação do processo emancipacionista em favor dos estados e pela definição de mecanismos legais que conferiram a iniciativa legislativa aos atores locais e o controle da maior parte do processo das emancipações às assembléias legislativas. No Rio Grande do Sul, como em todas unidades da federação, a regulamentação estadual determinou a potencialidade emancipacionista, por meio das leis que determinaram os passos do processo de criação de município e os limites ou exigências às localidades que desejavam sua emancipação.

Em conjunto, estímulos fiscais, instrumentos processuais favoráveis e a ampliação do estoque de localidades emancipáveis formaram o contexto institucional que determinou no Rio Grande do Sul um ambiente para que ocorressem decisões políticas extremamente favoráveis às emancipa-

MacDowell (1997). Similarmente, Shikida (1998) relaciona a estrutura do federalismo brasileiro à ocorrência do fenômeno político emancipacionista, por meio do conceito “restrição orçamentária não rígida”, no qual as transferências intergovernamentais (Fundo de Participação dos Municípios (FPM)), em regimes democráticos, incentivariam os atores a decidir favoravelmente pela emancipação onde fosse possível ampliar a disponibilidade de recursos às localidades emancipadas. Outras explicações, menos plausíveis que a vinculação direta com o regime político, fundamentam-se em vários aspectos do processo emancipacionista (causas societais e políticas) e variam muito quanto à abordagem teórico-epistemológica adotada. Porém, na maior parte dos casos, simplesmente não se sustentam diante de uma avaliação lógica ou de um teste empírico mais elaborado. Há explicações orientadas por uma abordagem funcionalista, como a de Bremaeker (1991, p. 33), segundo a qual as emancipações municipais responderiam a "uma lógica extremamente racional”. Outra explicação similar à anterior é desenvolvida por Mesquita. Utilizando uma abordagem sistêmica, a autora define que as causas últimas das emancipações municipais estariam no processo de modernização (MESQUITA, 1992, p. 170). Há, ainda, outras explicações para o fenômeno, como a apresentação de causas institucionais em Mello (1992) e as explicações das emancipações pelas motivações dos atores locais (KLERING, 1991; BREMAEKER, 1993). ções municipais ${ }^{4}$. Somou-se a isso a capacidade do poder Legislativo estadual de conquistar grande autonomia decisória sobre o processo emancipacionista. O Legislativo não sucumbiu às pressões do poder Executivo estadual. Isso manteve constante o contexto institucional favorável às emancipações, devido à preservação dos mecanismos legais permissivos, aos resultados eleitorais que sempre privaram o poder Executivo de uma coalizão majoritária e sólida e à atuação contínua de alguns dos membros da assembléia mais comprometidos com a causa municipalista.

As determinações institucionais e a autonomia do poder Legislativo explicariam a dimensão emancipacionista do Rio Grande do Sul, comparada às outras unidades da federação. Para descrever esse processo utilizarei uma abordagem histórico-institucional, analisando a dinâmica das relações entre os poderes Executivo e Legislativo estaduais para descrever a produção de regulamentações favoráveis às emancipações e de leis que determinaram a criação dos novos municípios. Explorarei esse processo nas últimas três seções deste texto; entretanto, antes disso pretendo contextualizar melhor o caráter peculiar da fragmentação e autonomia municipal brasileira comparando-a a situações similares em outros estados.

\section{FEDERALISMO, AUTONOMIA POLÍTICAE CRIAÇÃO DE GOVERNOS LOCAIS}

A literatura que descreve ou analisa a autonomia municipal e a criação de unidades de governo local permite repensar, em uma dimensão comparativa e normativa, o papel dos municípios no federalismo brasileiro. A primeira distinção observada entre o processo emancipacionista brasileiro e qualquer evento similar relatado em outros países é a quantidade de novas unidades locais criadas no Brasil nas últimas décadas. A realidade brasileira nessa área é singular, não existindo qualquer referência contemporânea a uma fragmentação interna tão acentuada na literatura internacio-

\footnotetext{
4 Em um estudo comparativo, que serviu de base para esta exposição sobre o Rio Grande do Sul, procurei demonstrar que a intensidade emancipacionista possui uma variação determinada conforme: a disponibilidade de localidades emancipáveis, a posição resultante da relação de forças entre o executivo e o legislativo estaduais e a presença de mecanismos institucionais federativos que transfiram recursos aos governos locais e que favoreceram a autonomia do legislativo estadual. Ver Tomio (2002a; 2002b).
} 
nal.

Os exemplos de criação de novas unidades de governo local ("new towns") indicam, normalmente, um planejamento mínimo dos níveis superiores de governo. Geralmente, eles referem-se à criação ou à reorganização de áreas suburbanas em grandes metrópoles. Como há uma intencionalidade político-administrativa no surgimento dessas unidades locais, os aspectos problematizados não são as causas, mas os efeitos urbanísticos, sócio-culturais e comportamentais que a criação das "new towns" acarre$\operatorname{tam}^{5}$. Contrastando com a experiência brasileira recente, todos esses casos relacionam a criação de governos locais com o processo de urbanização. Ou, mais especificamente, com a expansão populacional de grandes núcleos urbanos ou metrópoles. Nesse sentido, quando comparadas à ocorrência de processos similares em outros países, as emancipações municipais no Brasil distinguem-se porque são muito mais numerosas, concentram-se em áreas pouco urbanizadas e não são ordenadamente planejadas pelos níveis de governo mais abrangentes.

Explicando o processo de fragmentação de governos locais nos Estados Unidos, provavelmente o fenômeno mais comparável ao caso brasileiro, Wright (1975) e Caputo (1975) discutem o general revenue sharing ${ }^{6}$ na organização, no incremento, na extinção ou na fusão de governos locais nos Estados Unidos. Esses autores conclu-

5 Alguns estudos desse tipo tratam do empobrecimento e da homogeneização populacional na new town de Elisabeth, na Austrália (PEEL, 1995); do financiamento e planejamento, público e privado, no desenvolvimento de new towns em várias províncias canadenses (SKABURSKIS, 1989); das conseqüências do deslocamento populacional para as new towns das cidades-Estado de Hong Kong e Cingapura (VASOO, 1988); do comportamento social, do espírito comunitário e da satisfação dos moradores de new towns britânicas (BARDO \& BARDO, 1983); da crise e dos problemas sociais nas cinco novas cidades da área metropolitana de Paris (criadas na década de 1960) e dos limites do planejamento público em sua estruturação (GOURSOLAS \& ATLAS, 1980; DAGNAUD, 1981)

6 Segundo Caputo (1975, p. 131-134), o “general revenue sharing” foi um programa iniciado em 1972 de transferência de recursos fiscais (do governo federal para os governos locais) nos Estados Unidos, sendo uma das iniciativas políticas de descentralização do "new federalism” no governo Nixon. Esse tipo de transferência apresentaria três diferenças com relação a outros programas federais de ajuda a estados e governos locais americanos: primeiro, tinha pro- em que os efeitos das transferências de recursos às unidades subnacionais foram marginais na organização dos governos locais americanos. Segundo Wright, a fusão ou extinção de distritos educacionais e a criação de novos distritos especiais $^{7}$, principais elementos dinâmicos na estrutura de governos locais americanos, ocorreu independentemente do general revenue sharing, visto que ambos estavam excluídos do programa. A redução na quantidade de distritos educacionais atenderia a um processo de racionalização administrativa, em curso desde os anos 1940, enquanto o incremento dos distritos especiais seria resultante de outro processo, decorrente das políticas tributárias federais e estaduais: a crescente limitação na capacidade de cobrar taxas e impostos pelos outros governos locais, que transfeririam a administração de políticas específicas para esses distritos (WRIGHT, 1975, p. 102).

Os efeitos do general revenue sharing sobre a fragmentação dos governos locais com propósitos gerais teriam sido periféricos. Mais do que fomentar a criação de novas unidades ${ }^{8}$, a garantia de transferências federais teria promovido a preservação de algumas estruturas locais de governo. Assim, segundo as hipóteses de Wright, os

visões de fundos por cinco anos, reduzindo o controle anual dos congressistas sobre os recursos; segundo, permitia aos governos estaduais e locais uma grande liberdade na alocação dos recursos; terceiro, havia pouco controle burocrático sobre a aplicação dos recursos. Portanto, uma forma de transferência muito similar ao Fundo de Participação dos Municípios existente no Brasil.

7 Os distritos educacionais e os distritos especiais são unidades de governo local destinadas a um único propósito, diferenciadas, portanto, dos condados, municipalidades e townships que possuem propósitos gerais. Esses distritos existem na maioria dos estados americanos, sendo que cada distrito especial, que pode ou não ter a capacidade de cobrar impostos, tem jurisdição sobre as mais variadas áreas (portos, aeroportos, irrigação, parques, controle de desastres, combate ao fogo, hospitais, controle de pragas, cemitérios etc.), com exceção da educação, que é uma área exclusiva dos distritos educacionais ou dos governos com propósitos gerais (UNITED STATES OF AMERICA. BUREAU OF THE CENSUS, 1994, p. 9-11).

8 Segundo Wright (1975, p. 103-104), o programa de transferências federais general revenue sharing representaria em 1972 9\% dos recursos fiscais dos condados, 8\% das municipalidades e $10 \%$ das townships. Como o autor só especifica os valores agregados, torna-se impossível fazer comparações com transferências semelhantes no Brasil (como o FPM) e o impacto em governos locais com diferentes níveis populacionais. 
efeitos do programa de transferências sobre a fragmentação, extinção ou fusão dos governos locais americanos teriam sido: nulos, para os condados; limitados, para as municipalidades, já que as novas unidades criadas seriam resultantes da urbanização em áreas metropolitanas, e um pouco mais relevantes para as townships, já que teria limitado o declínio na quantidade dessas unidades (idem, p. 103-104).

Nas constatações sobre o federalismo americano e a fragmentação das unidades de governo local, quando comparadas ao caso brasileiro, aparecem, direta ou indiretamente, questões relevantes para esta investigação. Primeiro, há a tentativa de relacionar a disponibilidade de recursos fiscais à criação ou à sobrevivência de governos locais. A existência de mecanismos institucionais que garantiriam a transferência das esferas mais abrangentes de governo, de um valor mínimo que, somado às outras receitas, permitiria a funcionalidade das unidades locais, é um fator explicativo relevante para o problema ${ }^{9}$. Entretanto, a transferência de recursos, exclusivamente, não explicaria a criação ou preservação de unidades de governo local. Como a repartição fiscal é uma prática freqüente ${ }^{10}$, o papel da transferência seria limitado a estimular o processo. Provavelmente, outros condicionantes institucionais e proposições normativas teriam maior importância na geração de um ambiente político favorável à ocorrência de uma fragmentação dos governos locais ${ }^{11}$.

9 Se, no caso norte-americano, um programa federal de cinco anos com recursos relativamente marginais teria influenciado na preservação de unidades subnacionais, no caso brasileiro, a perenidade de fundos constitucionais que garantem a maior parte dos recursos fiscais da maioria dos governos locais deveriam ter efeitos muito mais amplos sobre a fragmentação de municípios brasileiros. Sobre esse ponto, ver Gomes e MacDowell (1997).

10 As unidades de governo local norte-americanas são majoritariamente dependentes de transferências fiscais das esferas mais abrangentes de governo (federal and state aid). Em conjunto, esses recursos representaram, nas últimas décadas, mais da metade do orçamento dos governos locais (NATHAN \& LAGO, 1990).

11 A questão normativa que orienta esses e outros autores norte-americanos não parece ser a preocupação, favorável ou contrária, com a ocorrência de uma grande onda de novos governos locais. Mas o retardamento do processo inverso, de fusão (“consolidation”) desses governos em favor de uma maior eficácia administrativa, sobretudo nas áreas metropolitanas. Seyler (1974, p. 159-169), por exemplo, enfatiza a necessidade de cooperação entre as unida-
Há também uma grande diferenciação na estrutura das divisões político-administrativas internas dos Estados Unidos e do Brasil. Isso implica graus muito diversos de autonomia dos governos locais e, em conseqüência, de impactos distintos provocados pela fragmentação das unidades subnacionais. Essa questão fornece novos subsídios para o debate normativo sobre as emancipações municipais brasileiras e é complementada pela comparação da extensão de atribuições e da quantidade de unidades de governo local em cada país.

Alguns autores brasileiros advogam favoravelmente à criação de municípios devido à seguinte comparação: no Brasil haveria um número pequeno de municípios e a relação entre município/área ou município/população seria muito grande quando comparado a outros países, como a França e os Estados Unidos, que estão entre os mais pródigos em unidades de governo local (aproximadamente 40 mil). Esse é um argumento pouco robusto, visto que a organização político-administrativa e o grau de autonomia municipal desses países são muito distintos da realidade brasileira (ver Tabela 1).

A França tem uma organização territorial estruturada em quatro níveis hierarquizados: o Estado, a região, o departamento e o município. A grande quantidade de municípios está vinculada à

des locais, por meio da fusão entre condados e municipalidades ou do estabelecimento de conselhos regionais de gestão. Marando (1973, p. 95-96), sem enfatizar tanto uma posição normativa, procura explicar o insucesso na fusão entre condados e municipalidades por meio das expectativas negativas dos eleitores (manifestadas em referendos), que, entre outros fatores, identificariam na fragmentação administrativa (entre condados, municipalidades e distritos especiais) uma capacidade maior na provisão de serviços públicos. Já Zimmerman (1974, p. 134-141) afirma que a fragmentação jurisdicional existente nas metrópoles seria o fator responsável por alguns problemas do modelo administrativo local americano, sendo que o estado teria um papel importante na definição de regras que estimulassem a racionalização administrativa. Por outro lado, o volume das emancipações municipais brasileiras parece ter deixado muito pouco espaço para proposições criativas quanto à organização e as inter-relações dos governos locais. O embate normativo foi muito extremado, sendo comum a defesa ou condenação intransigente da criação de novos municípios. O debate sobre formas de cooperação intergovernamental e alternativas institucionais locais na estrutura federativa nunca fizeram parte da agenda política, sendo marginalmente discutidos nos espaços de decisão política. 
forma de sua institucionalização, ocorrida em 1789 ("um município em cada vila, burgo, paróquia ou comunidade de província”). Entretanto, apesar de numerosos, os municípios franceses têm um grau muito reduzido de autonomia ${ }^{12}$. No modelo de Estado unitário francês, adotado em suas linhas básicas por outros países europeus, latino-americanos e africanos (MELLO, 1993, p. 39), a problematização das causas da criação de municípios não tem sentido, visto que eles têm institucionalização imediata diante da ocorrência de uma nova comunidade. Isso não significa dizer que os efeitos da fragmentação territorial sejam meramente administrativos, já que a recente reforma francesa indica uma pressão política pela descentralização.

TABELA 1 - GRAU DE AUTONOMIA E DEMOCRATIZAÇÃO INSTITUCIONAL DOS MUNICÍPIOS (OU SIMILARES) ${ }^{13}$

\begin{tabular}{|c|c|c|c|}
\hline País & $\begin{array}{c}\text { Separação de poderes e } \\
\text { eleição autônoma dos } \\
\text { governantes }\end{array}$ & $\begin{array}{c}\text { Autonomia local } \\
\text { (independência das decisões) }\end{array}$ & $\begin{array}{c}\text { Capacidade de gerar } \\
\text { recursos próprios }\end{array}$ \\
\hline Brasil & Generalizada & Muito extensa & $\begin{array}{c}\text { Existente, definida pela } \\
\text { Constituição Federal }\end{array}$ \\
\hline França & Parcial & Pouco extensa & $\begin{array}{c}\text { Restrita, supervisionada } \\
\text { pelo governo central }\end{array}$ \\
\hline Estados Unidos & $\begin{array}{c}\text { Variável, conforme o estado e e } \\
\text { entre os governos locais dos } \\
\text { estados }\end{array}$ & $\begin{array}{c}\text { Variável, conforme o estado e e } \\
\text { entre os governos locais dos } \\
\text { estados }\end{array}$ & $\begin{array}{c}\text { Variável, conforme o } \\
\text { estado entre os } \\
\text { governos locais dos } \\
\text { estados }\end{array}$ \\
\hline
\end{tabular}

FONTE: United States of America (1994), Teune (1995) e France (1996).

O outro caso destacado - a organização territorial norte-americana - é muitas vezes visto como o modelo típico de estrutura federalista. Os estados, como unidades federadas, possuem total independência na definição da quantidade, tipos, formas e grau de autonomia das unidades de go-

12 Na França, a autonomia local foi efetivada por lei após 1992. Somente o “conselho municipal”, com o número de membros proporcional à população, é eleito diretamente pela comunidade, sendo que seu poder deliberativo é restrito e orientado pelas instâncias superiores. O administrador municipal é eleito pelo conselho e, dentro de um sistema dual, executa as deliberações locais e representa o Estado no município, subordinando-se ao nível hierárquico superior (o departamento). A capacidade tributária municipal é restrita e quanto menor a população local maior é a supervisão orçamentária da burocracia estatal sobre o município (MELLO, 1993; FRANÇA, 1996).

13 O modelo para identificação do grau de autonomia e democratização utiliza como base as três variáveis fundamentais, conforme definidas por Teune (1995, p. 20-23), para verificação do desenvolvimento político democrático dos governos locais: 1) a eleição de governantes diretamente pela comunidade local e a separação de poderes entre os poderes Executivo e Legislativo, como procedimentos independentes dos níveis de governo mais abrangentes; 2) a autonomia das decisões tomadas por esses governantes (home-rule) e sua independência (não-confirmação ou regressão) com relação às autoridades dos níveis superiores e 3) a autoridade local para taxar e coletar recursos fiscais independentemente, mesmo que em pequena escala. verno local dentro de suas fronteiras ${ }^{14}$. Nos EUA, não há uma padronização de nomes para os governos locais, que podem variar conforme os estados. Para efeito estatístico o Bureau of the Census agrupa os governos locais em cinco tipos: três com propósitos gerais (condados, municipalidades e townships $)^{15}$ e dois com propósitos específicos (distritos educacionais e es-

14 A doutrina constitucional norte-americana (conhecida como "Dillon's Rule”, devido ao nome do juiz da Suprema Corte que a estabeleceu no século XIX) define as unidades locais como criaturas do governo estadual que, por princípio, poderia criá-las ou extingui-las livremente, a despeito dos interesses locais. Neste sentido, os condados, municipalidades e outros tipos de governos locais não são entes federativos, sendo que sua eventual autonomia é fruto de delegação dos legisladores estaduais. Na prática, contudo, apesar do "home rule" não ser garantido necessariamente, há uma histórica tradição de respeito à autonomia dos governos locais norte-americanos na maioria dos estados federados (RUTLEDGE, 1974; GRUMM \& MURPHY, 1974; PAGANO, 1990).

15 Dos três tipos de governos locais com propósitos gerais: 1) os condados (“county governments") existem em quase todo território norte-americano, menos em "parish" em Louisiania e "borough" no Alasca), sendo que, entre 1987 e 1992, foram criados três novos condados no Alasca e extintos outros dois devido à fusão com municipalidades; 2) as municipalidades (“municipal governments”) são distintas das townships por questões históricas e designam um "governo geral para uma concentração populacional 
peciais $)^{16}$. Portanto, a criação ou extinção de unidades locais parece ter seus efeitos limitados pela diferenciação do grau de autonomia delegado aos governos locais. Isso, juntamente com a prerrogativa dos estados em regulamentar integralmente a existência de suas subdivisões territoriais, permite respostas razoáveis tanto às demandas locais por autogoverno quanto à racionalidade administrativa e fiscal do estado.

Contrastada com os dois exemplos anteriores, a dimensão da autonomia municipal brasileira e de sua relação com a recente onda emancipacionista pode ser melhor avaliada. Apesar de ser uma federação, a divisão territorial segue padrões mais rígidos (mesmo que totalmente diferentes quanto ao conteúdo) do que no Estado unitário francês, sendo que toda organização dos entes políticos internos está institucionalizada nos níveis jurídicos mais elevados (a maior parte na própria Constituição Federal, com um papel regulador menor

específica de uma determinada área” e incluem diversas denominações estaduais (“cities”, “boroughs”, “towns”, "villages”), foram criadas 79 (quase todas na Califórnia, Carolina do Norte e no Texas) e extintas cinco unidades (em Vermont) entre 1987 e 1992 e 3) os townships ou "town governments" existem em 20 estados do Nordeste e Meio-Oeste americano com vários nomes ("plantations”, "locations", "municipal corporations" e "towns", que nem sempre são áreas predominantemente rurais), foram extintas 35 dessas unidades entre 1987 e 1992. Existem, em todos os três tipos, governos locais com 100 ou menos habitantes e alguns condados e municipalidades com milhões de habitantes (UNITED STATES OF AMERICA. BUREAU OF THE CENSUS, 1994, p. 7-9).

16 Em virtude dessa diferenciação interna, existe uma grande variação nas configurações que determinariam o grau de autonomia das unidades locais. Há localidades que elegem: prefeitos e representantes (poder Legislativo); outros em que só elegem os representantes que, por sua vez, nomeiam prefeitos ou gerentes e outras que possuem administradores indicados por instâncias superiores. Dentre os diferentes tipos de governos locais, há pelo menos 31 estados que têm o "home rule" (independência nas decisões políticas em diversos graus) garantido aos condados em regulamentações estaduais (HILLENBRAND, 1974, p. 92); enquanto 30 estados delegam esse mesmo direito em suas constituições às cidades (PAGANO, 1990, p. 101-102). Da mesma forma, a capacidade de gerar recursos autonomamente varia conforme as limitações impostas pelas unidades da federação (idem, p. 103-105). Entretanto, geralmente os tributos arrecadados localmente são significativos para o funcionamento desses governos, visto que podem representar até metade do total dos gastos das unidades locais (NATHAN \& LAGO, 1990, p. 38). sendo destinado às constituições estaduais e leis complementares). A federação é estruturada em três níveis (União, estados/Distrito Federal e municípios) não hierarquizados, mas eqüipolentes e autônomos, com suas competências políticas, administrativas e fiscais determinadas constitucionalmente.

O outro lado dessa faceta institucional determina que, mesmo sendo uma federação, como os Estados Unidos, no Brasil os estados não possuam qualquer poder formal sobre a extensão e qualidade das decisões internas dos municípios, pois esse poder não foi delegado pelos primeiros. Institucionalmente, sobre os assuntos municipais, somente cabe aos estados o poder de intervir (em casos definidos juridicamente); de definir a forma de distribuição de uma fração menor (1/4, transferência que é obrigatória) de um dos impostos que arrecada (Imposto sobre Circulação de Mercadorias e Serviços (ICMS)) e de regulamentar as condições mínimas exigidas para a criação de um município em seu território, bem como decidir sobre a emancipação municipal. De todas essas competências, a última é que permite uma interferência maior do estado sobre a organização municipal.

Em virtude disso, a autonomia é universalizada e padronizada nos municípios brasileiros. Todos elegem da mesma forma os mesmos tipos de governantes (que só variam na quantidade de vereadores, conforme a população local), têm a mesma independência e as mesmas subdivisões político-administrativas (distritos) e podem cobrar os mesmos tipos de impostos. Independentemente da complexidade sócio-econômica, extensão geográfica, quantidade e densidade populacional, há somente uma forma de governo local no Brasil.

Portanto, criar um município no Brasil, diferentemente da criação de unidades de governo local em outros países, significa gerar uma nova entidade federativa. Um novo município, com menos de mil habitantes, possui as mesmas prerrogativas dos municípios de milhões de pessoas. Os impactos políticos de um processo emancipacionista, na dimensão verificada nas últimas décadas, devem ser muito mais acentuados no caso brasileiro, sobretudo porque não há mecanismos institucionais eficazes que permitam conciliar os interesses autonomistas locais com a racionalidade generalizante das esferas mais abrangentes de governo. Em virtude disso, as 
modificações institucionais inscritas nas últimas constituições não oferecem soluções a esse problema da federação brasileira, limitando-se a promover mecanismos restritivos ou permissivos às emancipações municipais em momentos políticos distintos. Ou, mais especificamente, nos últimos 50 anos, com o estímulo das transferências fiscais inaugurados pela constituição de 1946, quando foi atribuído aos estados determinar o processo de fragmentação dos municípios, a ocorrência de ondas emancipacionistas variou em intensidade nos estados conforme o arranjo institucional e a relação entre os poderes Executivo e Legislativo na esfera estadual. Sem abordar os efeitos desse processo - as conseqüências diretas que as emancipações geraram nos governos municipais -, utilizarei o exemplo mais contundente (pelo menos em termos numéricos), o estado do Rio Grande do Sul, para descrever o processo de decisão política que gerou a multiplicação de governos lo- cais no Brasil.

\section{BREVE HISTÓRICO E CONTEXTUALIZA- ÇÃO DA CRIAÇÃO DE MUNICÍPIOS NO RIO GRANDE DO SUL}

Em todo o século XX, somente na década de 1970 não houve a produção de leis de criação de municípios no Rio Grande do Sul. Mais precisamente, entre 1964 e 1982 nenhum novo município foi criado e sete municípios foram extintos ${ }^{17}$. Nesse período, os estados perderam a competência de regulamentar a criação de municípios - situação somente repetida, em toda história republicana, pela Emenda Constitucional n. 15/1996. O regime militar, além de alterar a ordem institucional, reduziu as transferências fiscais e reprimiu firmemente as fragmentações territoriais que não eram de seu interesse - o que geralmente se restringia às emancipações nas regiões de fronteira ou de colonização da Amazônia e do Centro-Oeste.

TABELA 2 - QUANTIDADE DE MUNICÍPIOS NO RIO GRANDE DO SUL POR DÉCADA (1900-2000)

\begin{tabular}{|c|c|c|c|c|c|c|c|c|c|c|c|c|}
\hline & \multicolumn{10}{|c|}{ DÉCADAS } \\
\hline MUNICÍPIOS & 1900 & 1910 & 1920 & 1930 & 1940 & 1950 & 1960 & 1970 & 1980 & 1990 & 2000 \\
\hline Existentes & 63 & 66 & 71 & 80 & 88 & 92 & 150 & 232 & 232 & 333 & 497 \\
\hline Criados na década & 3 & 5 & 9 & 8 & 4 & 58 & 82 & 0 & 101 & 164 & - \\
\hline Crescimento na década (\%) & $5 \%$ & $8 \%$ & $13 \%$ & $10 \%$ & $5 \%$ & $63 \%$ & $55 \%$ & $0 \%$ & $44 \%$ & $49 \%$ & - \\
\hline
\end{tabular}

FONTES: IBGE (2005) e Rio Grande do Sul. Assembléia Legislativa (2005).

Um exame, década por década, das emancipações municipais gaúchas demonstra a semelhança de dois períodos históricos (ver Tabela 2). Entre os anos de 1950 e 1960 houve, proporcionalmente, o maior surto de emancipações, somente comparável às últimas duas décadas do século XX. Essa semelhança não é casual. As mesmas variáveis políticas (arranjo federativo, contexto institucional e relação de forças entre os poderes Legislativo e Executivo estadual favorável à criação de novos municípios) determinaram o ritmo emancipacionista.

Nesses dois períodos, que cruzam quatro décadas mas somente cerca de 20 anos de efetiva criação de municípios, foram criados mais de $80 \%$ dos municípios gaúchos. Os dois períodos favoreceram a criação de municípios por meio de um arranjo institucional descentralizador que incluiu a autonomia política estadual e os estímulos fiscais pela transferência constitucional de parte dos impostos recolhidos pelo governo federal. A transferência de recursos fiscais entre a União e os municípios foi uma inovação institucional da Constituição de 1946, mantida, mesmo que de maneira mais restrita, até mesmo pelas duas constituições impostas pela ditadura militar ${ }^{18}$. Como na década de 1980, também nos anos 1960 os atores políticos do Rio Grande do Sul participaram da corrida pelos recursos fiscais arrecadados pela União. Dos

17 Todas as sete extinções de municípios no Rio Grande do Sul resultaram de recursos ao Tribunal de Justiça. As extinções ocorreram entre 1964 e 1966, atingindo os seguintes municípios: Alto Alegre e Campos Borges (anexados a Espumoso), Capão do Leão (Pelotas), Fortaleza dos Valos (Cruz Alta), Hulha Negra (Bagé); Silveira Martins (Santa Maria), Vista Alegre (Nova Prata e Veranópolis). Esses municípios foram recriados entre 1982 e 1993 (IBGE, 1980). Além deles, dezessete consultas plebiscitárias não foram realizadas na década de 1960 em virtude da edição do Ato Institucional n. 2.

18 A Constituição de 1946, no § $4^{\circ}$ de seu art. 15, determinou a transferência, "em partes iguais” aos municípios do interior, de 10\% da arrecadação do Imposto de Renda. A Emenda Constitucional n. 5 de 1961 ampliou a participação dos municípios nesse imposto para $15 \%$. Além de ampliar o fundo com $10 \%$ 
140 municípios criados nesse período, mais de 80 foram emancipados nos últimos anos do regime democrático.

Em 1980, o Rio Grande do Sul estava dividido em 232 municípios. Logo no início da década, demandas locais pela criação de novos municípios começaram a chegar à Assembléia Legislativa. A maioria dos legisladores era favorável às emancipações e alguns eram militantes da causa municipalista. Por iniciativa dos últimos, criou-se em 1982 uma comissão permanente especialmente destinada a assessorar e encaminhar os processos de emancipações dentro do poder Legislativo: a Comissão de Assuntos Municipais (CAM). Desde o início dos trabalhos da Comissão, a perspectiva de utilizar as emancipações como um mecanismo para a ampliação das transferências fiscais sempre esteve presente ${ }^{19}$.

Na maior parte dos dois períodos democráticos analisados, as emancipações não sofreram oposição sistemática do poder Executivo gaúcho. Sem barreiras políticas, com uma estrutura burocrática emancipacionista dentro da Assembléia Legislativa (anos 1980 e 1990) e com os estímulos fiscais crescentes, os legisladores estaduais converteram os pedidos de emancipação em leis que criaram os municípios. Nesse processo, a transgressão à regulamentação do processo emancipacionista, definida na Constituição estadual ou em leis complementares estaduais e federais, foi comum nos dois

da receita sobre o imposto de “consumo de mercadorias”. O regime militar, por meio da Emenda Constitucional n. 18 de 1965, instituiu uma nova ordem tributária que criou o FPM (Fundo de Participação dos Municípios). Esta medida diminuiu a participação dos municípios para 10\% do IR e do IPI e determinou a forma de aplicação da maior parte desses recursos. Em 1969, por meio da Constituição imposta pela junta militar, o FPM foi reduzido para 5\% do IR e IPI. A partir do final da década de 1970, a participação do FPM sobre esses tributos foi sendo paulatinamente aumentada até 22,5\% do IR e IPI em 1993 (BARRETO, 1971; BRASIL, 1988). A União tem competência para estabelecer normas gerais que podem ser complementadas por legislação estadual. Na ausência de legislação federal, os Estados exercem competência legislativa plena.

19 Esse argumento foi reiterado várias vezes pelos deputados gaúchos. O teor dos discursos dos parlamentares foi retirado de publicações da comissão (MINCARONI, 1991), de transcrições de reuniões regulares dos deputados membros da CAM e de entrevistas e artigos em jornais de circulação no estado do Rio Grande do Sul, como Zero Hora e Correio do Povo (de Porto Alegre) e A Razão (de Santa Maria). períodos democráticos. Isso aconteceu, sobretudo, na primeira metade dos anos 1960, no final doa anos 1980 e na legislatura anterior à Emenda Constitucional n. 15/96. Nesses períodos, a maioria dos municípios não possuía a população exigida pela legislação complementar ${ }^{20}$.

Nos anos 1960 e, novamente, nos anos 1990, o poder Executivo estadual tornou-se opositor da criação de municípios. Pressionados a realizar transferências voluntárias e investimentos diretos nas novas municipalidades criadas nas legislaturas anteriores, alguns governadores gaúchos passaram a vetar as leis de criação de município. No entanto, geralmente a Assembléia Legislativa manteve suas deliberações por meio da derrubada dos vetos.

Por outro lado, nas emancipações municipais das décadas de 1950 e 1980 houve cooperação entre os poderes estaduais. Contudo, a maioria dos municípios criados nos anos 1960 e 1990 dependeu da capacidade de os legisladores estaduais manterem a autonomia de suas deliberações frente às pressões do poder Executivo. A maioria parlamentar favorável às emancipações conseguiu manter suas preferências e criar centenas de municípios, amparados nos mecanismos que organizam o processo legislativo e na debilidade do Executivo.

Nos dois períodos, conforme as emancipações avançaram no tempo, a população das localidades emancipadas foi diminuindo, ou seja, como seria logicamente esperado, mantidas as condições institucionais e a capacidade de decisão política favoráveis, o estoque de localidades emancipáveis de um estado tende a esgotar-se até seu limite. Primeiro são emancipados os distritos com condições mais favoráveis; quando estes não mais existem, são criados municípios que apresentam condições cada vez mais próximas às exigências legais mínimas ${ }^{21}$.

20 O ímpeto emancipacionista gaúcho dos anos 1980 resultou, segundo dados da Assembléia Legislativa, no crescimento de $12,88 \%$ na participação dos municípios do estado no total de recursos do FPM. Como até a promulgação da Lei Complementar federal n. 62/1989, a distribuição do FPM dos municípios do interior era semelhante a um jogo de soma zero entre todos os municípios do Brasil, quanto mais municípios um estado criasse maior seria sua participação no Fundo, em detrimento das unidades da federação que não fragmentassem seu território.

21 No Rio Grande do Sul, quando não havia mais municípios emancipáveis no início da década de 1990, a legislação foi reformada para permitir a criação de novos municípios. 
TABELA3 - ESTATÍSTICAS DESCRITIVAS SOBRE A POPULAÇÃO DOS MUNICÍPIOS EMANCIPADOS NO RIO GRANDE DO SUL (1954-2001)

\begin{tabular}{|c|c|c|c|c|c|c|c|c|c|}
\hline \multirow{2}{*}{$\begin{array}{c}\text { Estatísticas sobre a } \\
\text { população }\end{array}$} & \multicolumn{6}{|c|}{ Anos de instalação dos municípios } \\
\cline { 2 - 11 } & $\begin{array}{c}1954- \\
1955\end{array}$ & $\begin{array}{c}1959- \\
1960\end{array}$ & $\begin{array}{c}1961- \\
1963\end{array}$ & $\begin{array}{c}1964- \\
1965\end{array}$ & $\begin{array}{c}1981- \\
1982\end{array}$ & 1989 & 1993 & 1997 & 2001 \\
\hline Média & 20206 & 12505 & 12376 & 7776 & 14081 & 4657 & 3606 & 3373 & 2306 \\
\hline Máxima & 35100 & 17190 & 22720 & 11940 & 31995 & 17703 & 12467 & 6826 & 3927 \\
\hline Mínima & 10420 & 6930 & 4840 & 2720 & 4159 & 1047 & 1509 & 2151 & 1601 \\
\hline Desvio-padrão & 7153 & 3048 & 3896 & 2135 & 9331 & 2636 & 1979 & 1019 & 466 \\
\hline Mediana & 18520 & 12575 & 11755 & 8455 & 11062 & 3868 & 2945 & 3028 & 2353 \\
\hline
\end{tabular}

FONTE: IBGE (vários anos).

Uma análise diacrônica das emancipações torna possível visualizar melhor o processo de esgotamento do estoque de localidades emancipáveis (ver Tabela 3). Nos dois períodos, progressivamente diminuiu a média da população dos novos municípios. Além disso, esses municípios foram tornando-se mais homogêneos, o que é demonstrado pelo desvio-padrão da população dos novos municípios. Em meados dos anos 1960 e, sobretudo, no final dos anos 1990, somente micromunicípios foram criados no Rio Grande do Sul.

No Rio Grande do Sul, nas últimas duas décadas, a subdivisão dos municípios envolveu $70 \%$ dos municípios existentes no início da década de 1980. Também ocorreu preferencialmente entre os pequenos municípios do interior (mais sensíveis aos estímulos fiscais). Para a população local, a fragmentação territorial implica maior disponibilidade de recursos fiscais sem a necessidade de pagar-se mais impostos. Quando a emancipação envolve somente pequenos municípios, sem fontes extraordinárias de geração de impostos, o benefício é mútuo. Não há qualquer estímulo para os eleitores e para as lideranças locais tentarem bloquear o processo. Portanto, é razoável supor que futuras emancipações ocorrerão preferencialmente quando pequenos municípios forem fragmentados.

\section{INSTITUIÇÕES POLÍTICAS: CONTEXTO INSTITUCIONAL E REGULAMENTAÇÃO DAFRAGMENTAÇÃO MUNICIPAL}

O ritmo da fragmentação municipal no Brasil não resulta diretamente do regime político, democrático ou ditatorial, mas da determinação, entre os entes federativos, de qual esfera de decisão política está capacitada a regulamentar a criação de municípios. Indiferentemente ao regime, quan- do o poder central conseguiu obter os meios para limitar (parcial ou totalmente) a autonomia estadual sobre a fragmentação de seu território, as emancipações sempre foram substancialmente reduzidas. De uma maneira geral, nos períodos em que estados tiveram controle sobre o processo, cresceu o ritmo emancipacionista no Brasil, sobretudo quando os estímulos fiscais também eram favoráveis. No entanto, a variação na criação de municípios entre as unidades da federação dependeu das suas instituições e da dinâmica da interação entre os poderes Executivo e Legislativo estaduais (TOMIO, 2002a; 2002b).

Portanto, a variação no ritmo e na intensidade da produção de leis de criação de municípios é explicada pela dinâmica institucional, pelas preferências dos atores políticos estaduais e pela forma por que essas instituições limitaram as estratégias desses atores no período em que a autonomia estadual prevaleceu. No entanto, a explicação baseada no papel das instituições como regras do jogo é só uma dimensão do problema. Outra dimensão dessas instituições políticas - sua criação e manutenção - é determinante para a explicação das emancipações. Vista como um resultado político, a compreensão volta-se especialmente para o processo de decisão política que gerou essas instituições estaduais.

Nos dois últimos períodos democráticos, o grande incremento de municípios no território riograndense só foi possível devido aos critérios presentes na regulamentação do processo legislativo emancipacionista. Isso ocorreu porque a relação de forças, emancipacionistas e antiemancipacionistas, manteve-se em um equilíbrio que sempre favoreceu os atores ligados ao primeiro bloco. Especificamente, isso significou a 
maioria parlamentar que se posicionou favoravelmente à fragmentação territorial sempre conseguiu manter o controle do ritmo emancipacionista: nos momentos iniciais do processo, com a cooperação do poder Executivo e, quando a cooperação não existiu, construindo uma autonomia, pelo menos nessa matéria legislativa, que permitiu contrapor-se à oposição explícita dos governadores ${ }^{22}$.

Durante todo o primeiro período republicano, o Rio Grande do Sul viveu sob a Constituição castilhista de 1892. Essa Constituição afastou a Assembléia Legislativa de grande parte das decisões políticas. A Assembléia foi transformada em Assembléia dos Representantes, com a única atribuição de votar o orçamento estadual. A maior parte do poder Legislativo estadual foi transferido para as câmaras municipais, cujas atribuições eram propor leis e aprovar as elaboradas pelo poder Executivo em um prazo de um ano.

As alterações na divisão territorial do estado eram atribuição exclusiva das câmaras municipais envolvidas. O processo decisório era estabelecido pela Lei Orgânica de cada município. Em síntese as câmaras aceitavam os pedidos de anexação, desmembramento ou criação municipal; promoviam os plebiscitos e enviavam o projeto de emancipação ao Governador do Estado. Esse ator, com base nos pré-requisitos firmados pela Constituição Estadual, vetava ou promulgava o decreto de criação municipal. O processo decisório, portanto, estava restrito ao Presidente do Estado e aos chefes republicanos locais, que solicitavam as emancipações conforme seus interesses e conveniências.

22 Para compreender como o poder Legislativo deteve essa capacidade, descreverei historicamente o processo decisório da institucionalização política sobre divisão municipal no Rio Grande do Sul. Na explicação das transformações institucionais, utilizarei, basicamente, três noções da abordagem neo-institucionalista histórica: 1) a autonomia do Estado - o pressuposto que os atores envolvidos no processo decisório são fundamentalmente os atores estatais (no caso legisladores, governantes e burocracia pública) -; 2) o contexto institucional - a organização do Estado e as regras processuais sobre o processo legislativo - e 3) o "policy feedback" - isto é, como o legado político interfere no processo decisório e na formação de interesses e coalizões políticas. Essas noções reproduzem, mesmo que não fielmente, o modelo explicativo construído por Orloff (1993) para a explicação comparativa do surgimento e da dinâmica das políticas de pensões públicas na Inglaterra, no Canadá e nos Estados Unidos.
A Constituição de 1935 continuou mantendo a prerrogativa de alteração territorial nas câmaras municipais, incluindo apenas no processo decisório a Assembléia Legislativa como ponto final do processo emancipacionista. Houve nesse momento uma transição para as regras nos períodos democráticos mais recentes da história brasileira e gaúcha, com a Assembléia Legislativa adquirindo maiores prerrogativas no processo legislativo.

O ambiente institucional, inaugurado pela reconstitucionalização de 1946, incentivou mudanças institucionais no processo de emancipação municipal. Durante a Constituinte Estadual, os deputados iniciaram um franco debate para estipular os requisitos mínimos necessários para as emancipações municipais. A Constituição de 1935 serviu de espelho e condutor do debate de todo o processo constituinte estadual. A Comissão de Sistematização copiou grande parte dessa Constituição, alterando os pontos em desacordo com a expectativa de democracia vivida no ambiente político.

A primeira Lei Complementar visando a alterações na divisão territorial do Estado foi a de n. 534, de 31 de dezembro de 1948. Os requisitos básicos eram população mínima de 20 mil habitantes e renda mínima de 600 mil cruzeiros. O processo legislativo estabelecido por essa lei era o seguinte: 1/5 dos eleitores da zona emancipada formava uma comissão emancipacionista, que formalizava o pedido junto à Assembléia Legislativa ou ao Governador do Estado; o processo era encaminhado a uma Comissão Revisora da divisão territorial do Estado, órgão ligado à Secretaria de Agricultura para o parecer técnico. Feito o parecer, encaminhava-se o processo à Comissão de Constituição e Justiça (CCJ), que detinha o poder de arquivar o pedido ou, por meio de resolução, determinar a realização de consulta popular. Se aprovado por maioria simples dos votantes, o processo ia à sanção do Governador. A existência de uma Comissão Técnica ligada ao poder Executivo tinha por objetivo alertar os deputados contra a formação de municípios sem condições de sobrevivência. Entretanto, os legisladores gaúchos passaram por cima de todos os pareceres contrários ${ }^{23}$.

23 O Supremo Tribunal Federal declarou inconstitucional a Lei n. 534, que violava a Constituição Estadual, que, como a carta de 1935, atribuía aos municípios a prerrogativa de definir seus limites territoriais (de anexação, 
A Lei n. 2 116/53 regeu as emancipações municipais até 1960. De autoria do Partido Trabalhista Brasileiro (PTB), essa lei fixou os anos de milésimo 3 e 8 para a divisão territorial, datas para plebiscitos e eleições e confirmou a existência de uma Comissão Revisora de Divisão Territorial, à qual cabia o parecer para orientar a CCJ. Essa Comissão externa representava sérias dificuldades ao poder Legislativo; mesmo sendo um órgão consultivo, seus pareceres eram usados pelos municípios-mãe para impedir judicialmente a realização de plebiscitos. Outra dificuldade imposta pela existência da Comissão Revisora residia no fato de ser convocada pelo Governador. $\mathrm{O}$ atraso da convocação pelo Governador impedia o cumprimento dos prazos legais, obrigando os deputados a realizarem uma série de alterações na Lei Complementar a fim de adequá-la à conjuntura.

A Lei n. 2 116/53 impedia o andamento mais ágil dos processos de emancipação municipal e levou o PTB de Leonel Brizola a promulgar em 1960 a Lei Complementar n. 4 054, acabando com a Comissão Revisora de Divisão Territorial e com as datas específicas para realização de plebiscitos e eleições municipais; em suas disposições gerais e transitórias, a lei deu ensejo a que os municípios com processos arquivados na Assembléia pudessem ser avaliados fora dos qüinqüênios, possibilitando a emancipação de cinco municípios antes de 1963.

A disposição da Assembléia em facilitar as emancipações também se evidenciou em outras medidas com a intenção de prorrogar prazos para inscrição de Comissões, desrespeitar as exigências legais e na promulgação de duas emendas constitucionais: a Graeff, de 1958, e a Marcantônio, de 1963. Na primeira, a exigência populacional para a emancipação foi baixada para 8 mil habitantes caso a renda da zona emancipanda fosse três vezes superior à exigida por lei; na segunda, esse critério da renda foi rebaixado para o dobro da exigida pela lei complementar.

A primeira constatação a respeito da legislação estadual gaúcha, que definiu os requisitos mínimos para as emancipações municipais, é sua crescente permissividade, seja quando comparada às legislações de outros estados, seja com as regras preexistentes no próprio Rio Grande do Sul (ver a Tabela 4).

TABELA4-REQUISITOS MÍNIMOSPARAAEMANCIPAÇÃO DE MUNICÍPIOS NO RIO GRANDEDOSUL, POR PERÍODO

\begin{tabular}{|c|c|c|}
\hline $\begin{array}{c}\text { Período/ } \\
\text { legislação }\end{array}$ & $\begin{array}{c}\text { População/ } \\
\text { eleitorado }\end{array}$ & Outros requisitos \\
\hline $\begin{array}{l}\text { 1892-1930 } \\
\text { Constituição } \\
\text { Estadual }\end{array}$ & $\begin{array}{c}20000 \\
\text { habitantes }\end{array}$ & $\begin{array}{l}\text { - A prerrogativa de anexar, desmembrar e criar novos municípios } \\
\text { pertence às Câmaras de Vereadores envolvidas; } \\
\text { - aprovação da maioria do eleitorado da região e } \\
\text { - sanção do Governador do Estado. }\end{array}$ \\
\hline $\begin{array}{l}1935-1938 \\
\text { Constituição } \\
\text { Estadual }\end{array}$ & $\begin{array}{c}20000 \\
\text { habitantes }\end{array}$ & $\begin{array}{l}\text { - A prerrogativa de anexar, desmembrar e criar novos municípios } \\
\text { pertence às Câmaras de Vereadores envolvidas; } \\
\text { - aprovação pela Assembléia Legislativa mediante apresentação da } \\
\text { proposta pelo Governador do Estado e } \\
\text { - receita mínima fixada em } 300: 000 \$ 000 \text {. }\end{array}$ \\
\hline $\begin{array}{c}\text { 1938-1948 } \\
\text { Decreto-lei } \\
\text { n. } 311 \text { de } \\
\text { 02.mar.1938 } \\
\text { Decreto-lei } \\
\text { n. } 720 \text { de } \\
\text { 29.dez.1944 }\end{array}$ & $\begin{array}{c}30000 \\
\text { habitantes }\end{array}$ & $\begin{array}{l}\text { - As alterações na divisão territorial do estado nos de milésimo } 3 \text { e 8; } \\
\text { - por iniciativa do Interventor Federal mediante instrução do Conselho } \\
\text { nacional de Geografia e } \\
\text { - fixa em } 1948 \text { e } 1953 \text { os anos para alteração na divisão territorial do } \\
\text { estado. }\end{array}$ \\
\hline
\end{tabular}

desmembramento ou emancipação municipal). A inconstitucionalidade somente foi resolvida pela bancada do Partido Social-Democrata que, por meio de seu líder, Deputado Vieira da Cunha, elaborou a Emenda Constituci- onal n. 2, de 6 de dezembro de 1952. Ela atribuiu à Assembléia Legislativa, com a sanção do Governador, a prerrogativa de decretação de plebiscito para as divisões territoriais (ver TOMIO \& CANTO, 2003). 


\begin{tabular}{|c|c|c|}
\hline $\begin{array}{c}1948-1952 \\
\text { Constituição } \\
\text { estadual } \\
\text { LC estadual } \\
\text { n. } 534 / 48\end{array}$ & $\begin{array}{c}20000 \\
\text { habitantes }\end{array}$ & $\begin{array}{l}\text { - Anexação e desmembramento de distritos e subdistritos compete às } \\
\text { Câmaras de Vereadores ou 1/5 dos eleitores de cada área; } \\
\text { - para criação de municípios a iniciativa é exclusiva de } 1 / 5 \text { dos } \\
\text { eleitores locais, que formarão uma Comissão; } \\
\text { - plebiscito a partir de Resolução da Assembléia Legislativa; } \\
\text { - os eleitores votantes serão os residentes na localidade à mais de } \\
\text { dois anos; } \\
\text { - receita de Cr\$ } 600 \text { mil; } \\
\text { - sanção final do Governador e } \\
\text { - divisões em anos de milésimo } 3 \text { e } 8 \text {. }\end{array}$ \\
\hline $\begin{array}{l}\text { 1952-1967 } \\
\text { Emenda } \\
\text { Constitucional } \mathrm{n} \text {. } \\
\text { 02/52 e LC } \\
\text { Estadual } \\
\mathrm{n} .2116 / 53 \text { e } \\
4054 / 60\end{array}$ & $\begin{array}{c}12000 / \\
8000 \\
\text { habitantes }\end{array}$ & $\begin{array}{l}\text { - Plebiscito por lei ordinária (sanção do Governador); } \\
\text { - receita tributária suficiente e } \\
\text { - anuência da população interessada. }\end{array}$ \\
\hline $\begin{array}{c}1967-1990 \\
\text { LC Federal } \\
01 / 67 ; 28 / 75 \\
32 / 77,33 / 78 \\
39 / 80 ; 46 / 84\end{array}$ & $\begin{array}{c}10000 \\
\text { habitantes }\end{array}$ & $\begin{array}{l}\text { - Dez por cento de eleitores entre a população; } \\
\text { - duzentas casas ou prédios no núcleo urbano; } \\
\text { - arrecadação, no último exercício, de } 5 / 1000 \text { da receita estadual de } \\
\text { impostos; } \\
\text { - representação de } 100 \text { eleitores da área emancipanda; } \\
\text { - plebiscito decretado pela Assembléia Legislativa (Decreto Legislati- } \\
\text { vo) e } \\
\text { - plebiscito: maioria absoluta dos eleitores da área e } 50 \% \text { de compa- } \\
\text { recimento. }\end{array}$ \\
\hline $\begin{array}{l}1990-. . \\
\text { LC Estadual } \\
9070-9089 / 90\end{array}$ & $\begin{array}{c}1800 \\
\text { eleitores }\end{array}$ & $\begin{array}{l}\text { - População: } 1800 \text { eleitores "ou" } 5000 \text { habitantes; } \\
\text { - } 150 \text { casas ou prédios no núcleo urbano; } \\
\text { - condições reais de desenvolvimento; } \\
\text { - cem eleitores da área emancipanda para formar a comissão emanci- } \\
\text { pacionista; } \\
\text { - sanção do Governador ao plebiscito (Projeto de Lei) e } \\
\text { - plebiscito: maioria, com, no mínimo, } 50 \% \text { de comparecimento. }\end{array}$ \\
\hline
\end{tabular}

A interrupção das emancipações, no Rio Grande do Sul e no restante do país, não ocorreu pela simples imposição, em 1967, de uma legislação mais restritiva pelo governo federal; essa legislação só teve o objetivo de disciplinar a criação de municípios consentidos pelo governo federal autoritário. Foi a ruptura institucional, a violência centralizadora e as sanções políticas impostas pelo regime de 1964 que, claramente reconhecidas enquanto ameaças reais pelos atores políticos estaduais, cessou o surto emancipacionista dos anos 1950 e 1960. A regulamentação expressa na Lei Complementar federal n. 01/1967, acrescida à diminuição das transferências fiscais aos municípios, somente arrefeceu os ânimos (já prévia e violentamente apagados) dos emancipacionistas gaúchos.

No final do regime militar, os interesses municipalistas voltaram à tona na Assembléia Legislativa. Com um ambiente político mais favo- rável, os legisladores passaram a controlar novamente o processo emancipacionista, mesmo que por meio de critérios federais indesejados - o que, no entanto, não impediu a criação de mais de uma centena de municípios na década de 1980.

A principal prerrogativa institucional sobre os procedimentos que definem os passos da emancipação, que delegou ao poder Legislativo o controle da criação de municípios, encontra-se em dois pontos expressos nas últimas constituições brasileiras: primeiro, a Assembléia Legislativa é o único espaço de poder estatal que recebe as demandas sobre questões que envolvam a divisão política do território estadual; segundo, compete exclusivamente ao poder Legislativo a deliberação sobre a realização de plebiscitos e referendos, sem a necessidade de sanção do poder Executivo.

O monopólio do poder Legislativo sobre esses aspectos fundamentais da emancipação munici- 
pal é comum a toda federação. Caso o poder Executivo não tenha controle sobre a maioria da Assembléia, todo o processo, da constatação dos requisitos à deliberação sobre o plebiscito, passam ao largo dos governadores. Esses somente podem vetar o momento final, que é a lei de criação do município - algo extremamente impopular, já que além, de contrapor-se ao poder Legislativo, também é necessário negar a soberania popular expressa pela votação plebiscitária.

No Rio Grande do Sul, a legislação estadual, tanto nas décadas de 1950-1960 quanto nos anos 1990, legou algumas características específicas a esses dois mecanismos institucionais. A primeira atribui exclusivamente às comissões emancipacionistas das localidades o direito de iniciar o processo. Portanto, impediu que o poder Executivo ou os deputados pudessem legislar diretamente sobre a criação de um município sem que a população se organizasse.

Isso, aparentemente, limita o ímpeto emancipacionista dos políticos eleitos. No entanto, para o poder Legislativo, com uma maioria favorável às emancipações, esse mecanismo reforçou a capacidade de sucesso emancipacionista: 1) pela impessoalidade da origem das leis, que restringe a barganha intraparlamentar pelo apadrinhamento clientelista; 2) pela necessidade de construir uma burocracia na Assembléia para organizar e assessorar as demandas emancipacionistas ou 3) pela estruturação de grupos de pressão que, presentes no Legislativo, orientam as expectativas eleitorais futuras das autoridades, tornando-as mais sensíveis à satisfação das demandas do eleitorado e das lideranças locais. No Rio Grande do Sul, as centenas de pedidos de emancipação em cada legislatura ampliaram a eficácia desse mecanismo institucional, o que proporcionou à maioria dos legisladores as condições de resistir à pressão contrária do poder Executivo.

A outra característica tem um efeito unicamente restritivo em relação às emancipações municipais e só está presente na legislação estadual gaúcha. A autorização do plebiscito tem de ser feita por meio de lei ordinária, ao contrário do que determinam as constituições Federal e Estadual. Depois da Constituição Federal de 1988, isso não ocorreu em nenhum outro estado, onde a consulta é autorizada por decreto ou resolução do poder Legislativo. O Governador do Rio Grande do Sul tem, portanto, duas oportunidades de veto à cria- ção de municípios. No caso da aprovação da consulta plebiscitária, esse veto permite ao poder Executivo evitar a pressão local e a acusação de contrariar a vontade popular. Além disso, o veto exige, para ser derrubado, a maioria absoluta dos votos na Assembléia, ao contrário da lei, que é aprovada por maioria simples. Mesmo com o uso desse expediente, em alguns momentos nos anos 1960 e sistematicamente nos anos 1990, os governadores não conseguiram evitar a onda emancipacionista. O volume de demandas locais, a maioria parlamentar favorável às emancipações e a inexistência de uma maioria governista sólida no parlamento impediram que o poder Executivo exercesse suas preferências contrárias às emancipações.

A similaridade entre as legislações estaduais, com 30 anos de diferença, revela a forma que o processo de regulamentação ocorreu historicamente no Rio Grande do Sul. No início dos anos 1980, as principais lideranças municipalistas da Assembléia, que eram ligadas aos partidos de oposição (Partido do Movimento Democrático Brasileiro (PMDB) e Partido Democrático Trabalhista (PDT)), com maioria na Assembléia, passaram, paulatinamente, a questionar a legitimidade da legislação produzida pelo regime militar e recuperar o legado institucional estadual.

No meio da década, com o início da Nova República, o Deputado Estadual Algir Lorenzon (PMDB) deu entrada em um PLC (Projeto de Lei Complementar), arquivado pela inconstitucionalidade. Essa proposição instituiria uma regulamentação completa sobre as emancipações no estado. As doze emancipações municipais do início da década geraram novas demandas locais que não atendiam aos requisitos da Lei Complementar federal n. 1/1967. Com o esgotamento das localidades emancipáveis, o PLC renovaria as expectativas emancipacionistas.

No entanto, a confrontação direta com a institucionalidade, que a promulgação da lei implicaria, não foi adotada pelos atores políticos. A estratégia dos emancipacionistas gaúchos foi, simplesmente, desconhecer a regulamentação presente na legislação federal. Havia um consenso, entre a maioria dos membros do poder Legislativo e o poder Executivo estadual (o Governador Pedro Simon, do PMDB) a favor das emancipações. Elas ampliavam a participação estadual nas transferências do Fundo de Participação dos Municípios 
(FPM), o que reduziu a oposição a interesses localizados em alguns dos casos de emancipação.

Antes de aprovar as emancipações municipais dos anos 1980, as lideranças municipalistas da Assembléia criaram a Comissão de Assuntos Municipais (CAM). Isso alterou o caminho que as demandas emancipacionistas locais deviam percorrer no poder Legislativo. Essa comissão técnica permanente foi criada explicitamente para facilitar o trâmite dos projetos de lei (PLs) que criariam os futuros municípios. Enquanto parte do contexto institucional que permitiu as emancipações gaúchas, a criação da CAM concentrou os esforços dos parlamentares interessados na matéria; além disso, forneceu a burocracia necessária a seus interesses, dando a esses deputados maior controle sobre o processo legislativo. Depois do pedido de emancipação ingressar na Assembléia, cabe aos deputados da CAM o exame do mérito da solicitação e da satisfação das exigências legais. É nesse momento que um processo pode ser abortado ou protelado indefinidamente, caso os interesses contrários prevaleçam ${ }^{24}$. A CAM redige os projetos de lei para a realização do plebiscito, caso essa consulta tenha apresentado resultados positivos para a criação do município. Quando uma emancipação recebeu parecer favorável na Comissão, raramente ela foi interrompida pela Comissão de Constituição e Justiça (CCJ) ou pelo plenário.

Vários mecanismos, eleitorais e procedimentais, favorecem a posição emancipacionista: 1) a proposição legislativa aprovada pela CAM tem origem exógena ao parlamento e é coletiva, não sendo subscrita por nenhum deputado; 2) apesar

24 ACAM detém algo semelhante ao "gatekeeping power" ("poder de fechar as portas"), descrito no modelo distributivista da abordagem neo-institucionalista da escolha racional (LIMONGI, 1993, p. 12). Não parece, no entanto, que essa capacidade da Comissão sirva a uma troca de votos ("logroll") entre os parlamentares. Normalmente, somente as emancipações que contrariam interesses capazes de sensibilizar as expectativas eleitorais futuras dos deputados são abortadas na própria CAM. Oposição na base parlamentar dos legisladores ou movimentos antiemancipacionistas em municípios importantes e com grande população são os mais capazes de exercer pressão. O caso da não-emancipação do distrito de Camobi, pertencente ao Município de Santa Maria, ilustra esse tipo de situação, visto que essa localidade reunia melhores condições para tornar-se município que a imensa maioria das emancipações bem-sucedidas. de parte dos parlamentares concentrarem seus votos em uma região do estado, o efeito da alocação concentrada de recursos (a emancipação é uma lei típica de atendimento a clientelas, com benefícios particulares e custos generalizados) não pode ser monopolizado por nenhum parlamentar; 3) devido aos prazos legais, a votação dos projetos de lei é temporalmente concentrada, muitas vezes são votados em uma mesma seção, o que reduz os riscos de um parlamentar aprovar somente projetos vinculados aos interesses de sua base eleitoral; 4) o projeto de lei gerado na CAM, mesmo não sendo uma resolução fechada (já que qualquer parlamentar tem a capacidade de emendálo), dada a simplicidade de sua redação, torna a votação dos deputados quase plebiscitária, com o plenário só podendo rejeitá-lo ou aprová-lo; 5) a consulta plebiscitária é uma matéria cuja reprovação desabona o perfil democrático do parlamentar e, caso o deputado aprove sua realização, dificilmente ele recusar-se-á a votar a favor da criação de um município se o plebiscito for favorável; 6) como os governadores não possuíam maioria sólida na Assembléia, contrariar a emancipação, mesmo por um deputado desinteressado na matéria, geraria somente a expectativa de perdas eleitorais futuras que, dados a dimensão e o ritmo emancipacionista gaúcho, poderiam comprometer sua reeleição. Juntos, esses fatores tornaram quase imbatível a criação de municípios no Rio Grande do Sul.

A CAM, ao reunir uma burocracia, recursos humanos e financeiros e as lideranças políticas municipalistas pertencentes a diversos partidos ${ }^{25}$, serviu também como estrutura político-ideológica propagadora das emancipações, no Rio Grande do Sul e fora do seu território. A comissão atuou como uma entidade "guarda-chuva", reunindo e organizando vários grupos de interesse municipalistas gaúchos (como a Federação das Associações de Municípios do Rio Grande do Sul (FAMURS), as comissões emancipacionistas, alguns núcleos acadêmicos e outras associações municipais). Também atuou como parte de uma

25 Em um levantamento hemerográfico, em que foram recuperadas todas as matérias relacionadas às emancipações municipais (editadas, entre 1988 e 1996, no jornal A Razão, sediado em Santa Maria), foi possível constatar que a vinculação partidária das autoridades não determina a variação de sua manifestação pública (contrária ou favorável) a respeito da fragmentação territorial (TOMIO, 1998). 
rede nacional, realizando intercâmbio de informações e agregando esforços com outras organizações no Brasil (como as suas congêneres em outras assembléias estaduais, a Fundação Prefeito Faria Lima-Centro de Estudos e Pesquisas sobre Administração Municipal (Cepam) e o Instituto Brasileiro de Administração Municipal (IBAM), a Frente Municipalista Nacional e as associações de municípios estaduais).

Com as novas regras da constituição de 1988, a Assembléia Legislativa, a partir de um PLC de autoria do Presidente da CAM, Deputado Hélio Musskopf (PMDB), renovou os interesses emancipacionistas de seus parlamentares. Eles facilitaram (legalmente) a criação de novos municípios por meio da aprovação das leis complementares estaduais n. 9 070/1990 e 9 089/1990. O par de leis foi resultado da negociação entre os poderes Legislativo e Executivo. Apesar de o último ter consentido nas emancipações dos anos oitenta, a primeira lei aprovada teve um veto parcial. Esse veto foi aceito pela Assembléia com a justificativa de que os requisitos mínimos eram considerados, pelo Governador Sinval Guazzeli (PMDB), muito permissivos e contrários ao interesse público. O próprio Executivo enviou um PLC para substituir a parte vetada, que foi aprovado pelos legisladores 26 .

De fato, havia pouca diferença entre os requisitos da primeira Lei Complementar (n. 9 070/90), originada de emenda coletiva dos parlamentares, e os presentes na lei enviada pelo poder Executivo (n. 9 089/90): trezentos eleitores e 1000 habitantes a mais. A permissividade da lei deu-se pela interpretação que os legisladores deram-lhe. A presença da conjunção "ou” tornou letra morta o requisito populacional, reduzindo-o, na prática, a muito menos da metade do que exigia a lei complementar (menos de dois ao invés de 5000 habitantes). A intenção expressa na lei complementar, acordada entre os poderes Executivo e Legislativo, sucumbiu diante dos interesses emancipacionistas.

A aprovação de uma lei que facilitava as emancipações municipais, em um momento em que a relação de forças entre Executivo e Legislativo favorecia os interesses emancipacionistas, determinou a continuidade no ritmo da criação de mu-

26 Detalhes sobre a tramitação dos PLCs na Assembléia Legislativa gaúcha podem ser vistos em Tomio (2002a; p. 266). nicípios no Rio Grande do Sul. Aprovar uma lei complementar exige a manifestação favorável da maioria absoluta dos parlamentares. A ausência de maioria governista sólida na Assembléia Legislativa, durante os anos 1990, gerou uma situação de equilíbrio que impediu as tentativas posteriores de reformar a legislação.

Todos os PLCs que ingressaram na Assembléia Legislativa foram arquivados antes de ir ao plenário. A estratégia dos deputados emancipacionistas foi manter a legislação, mesmo que isso não atendesse integralmente a suas preferência. Em virtude disso, aceitaram os constantes duplos vetos do Executivo ante a possibilidade de ver emendas de última hora prosperarem e perder as votações de um PLC no plenário. A necessidade de maioria absoluta, difícil de ser alcançada por ambos os lados, favoreceu a estabilidade da regulamentação sobre as emancipações no estado.

V. RELAÇÕES ENTRE OS PODERES EXECU-

TIVO E LEGISLATIVO E O PROCESSO DECISÓRIO DA CRIAÇÃO DE NOVOS MUNICÍPIOS

Quando um pedido de criação de município é iniciado na Assembléia Legislativa, a emancipação municipal é um dos resultados possíveis. No processo legislativo gaúcho, a solicitação emancipacionista obrigatoriamente deve percorrer nove diferentes momentos de decisão política (oportunidades de veto). Em cada um desses momentos, diferentes atores políticos manifestam suas preferências a respeito da criação do município demandado. A maioria dessas decisões é coletiva, como no caso em que o eleitorado manifesta-se no plebiscito e nas seis decisões tomadas pelos deputados estaduais; somente duas decisões são tomadas por um ator individual. Os dois momentos em que o governador decide se sanciona ou veta as leis são: a lei que determina a realização do plebiscito e a lei de criação do município.

Seguindo passo a passo o processo decisório é possível verificar o que ocorreu com os 398 e 194 pedidos de emancipação que, entre 1987-1999 e 1953-1965, respectivamente, ingressaram no poder Legislativo gaúcho e como $64 \%$ e $76 \%$ desses pedidos converteram-se em novos municípios (ver tabelas 5 e 6). As comissões da Assembléia Legislativa e os dois primeiros momentos de veto de que o Legislativo dispõe são responsáveis pela maior parcela de rejeição de projetos de emancipação. Essas comissões têm poder terminativo 
sobre as matérias técnicas, o que as tornam o momento mais discreto para encerrar o trâmite de uma lei indesejada ${ }^{27}$. No plenário da Assembléia (o terceiro veto legislativo), a maioria dos parlamentares votou poucas vezes contrariamente à aprovação da lei que autorizava a consulta plebiscitária. Em todas as vezes que a lei do plebiscito foi aprovada, o poder Executivo exerceu seu primeiro direito de veto centenas de vezes. A maioria absoluta da Assembléia (no seu quarto momento de decisão) somente deixou de derrubar pouco mais de um décimo desses vetos.

TABELA5 - TRAMITAÇÃO E RESULTADOS DO PROCESSO DECISÓRIO DAS EMANCIPAÇÕES MUNICIPAIS NO RIO GRANDE DO SUL (1987-2002)

\begin{tabular}{|c|c|c|c|c|c|c|c|}
\hline \multirow[b]{2}{*}{$\begin{array}{l}\text { Atores } \\
\text { políticos }\end{array}$} & \multirow[b]{2}{*}{ Resultado } & \multicolumn{4}{|c|}{ GOVERNADORES } & \multirow{2}{*}{\multicolumn{2}{|c|}{ Total }} \\
\hline & & \begin{tabular}{|c|} 
(1987-1990) \\
Governo \\
PMDB \\
(Simon/Guaz- \\
zeli)
\end{tabular} & 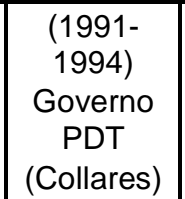 & $\begin{array}{c}\text { (1995-1998) } \\
\text { Governo } \\
\text { PMDB } \\
\text { (Brito) }\end{array}$ & \begin{tabular}{|c|}
$(1999-$ \\
$2002)$ \\
Governo \\
PT \\
(Dutra) \\
\end{tabular} & & \\
\hline $\begin{array}{l}\text { Líderes } \\
\text { locais }\end{array}$ & $\begin{array}{c}\text { Pedidos Protocolados } \\
\text { na Assembléia } \\
\text { Legislativa }\end{array}$ & 99 (100\%) & $112(100 \%)$ & $147(100 \%)$ & $40(100 \%)$ & 398 & $(100 \%)$ \\
\hline \multirow{6}{*}{$\begin{array}{l}\text { Deputados } \\
\text { nas } \\
\text { comissões } \\
\text { (CAM e } \\
\text { CCJ) da } \\
\text { Assembléia } \\
\text { Legislativa }\end{array}$} & $\begin{array}{c}\text { Pedidos em } \\
\text { tramitação na CAM }\end{array}$ & - & - & - & 40 & 40 & $(10 \%)$ \\
\hline & Pedidos rejeitados & 6 & 17 & 27 & - & 50 & $(13 \%)$ \\
\hline & Pela CAM & 1 & 1 & 12 & - & 14 & $(4 \%)$ \\
\hline & Pela CCJ & - & 10 & 12 & - & 22 & $(6 \%)$ \\
\hline & $\begin{array}{l}\text { Pelas comissões } \\
\text { (sem referências) }\end{array}$ & 5 & 6 & 3 & - & 14 & $(4 \%)$ \\
\hline & $\begin{array}{l}\text { Pedidos aceitos } \\
\text { (subtotal) }\end{array}$ & 93 & 95 & 120 & - & 308 & $(77 \%)$ \\
\hline \multirow{2}{*}{$\begin{array}{c}\text { Deputados } \\
\text { no Plenário } \\
\text { da } \\
\text { Assembléia } \\
\text { Legislativa } \\
\end{array}$} & $\begin{array}{l}\text { Leis (plebiscito) } \\
\text { rejeitadas }\end{array}$ & - & - & 21 & - & 21 & $(5 \%)$ \\
\hline & $\begin{array}{l}\text { Leis aprovadas } \\
\text { (subtotal) }\end{array}$ & 93 & 95 & 99 & - & 287 & $(72 \%)$ \\
\hline \begin{tabular}{c|} 
Poder \\
Executivo
\end{tabular} & $\begin{array}{l}\text { Leis (plebiscito) } \\
\text { vetadas }\end{array}$ & - & 86 & 94 & - & 180 & $(45 \%)$ \\
\hline \multirow{3}{*}{$\begin{array}{c}\text { Deputados } \\
\text { no Plenário } \\
\text { da } \\
\text { Assembléia } \\
\text { Legislativa }\end{array}$} & $\begin{array}{l}\text { Vetos (plebiscito) } \\
\text { aceitos }\end{array}$ & - & - & 24 & - & 24 & $(6 \%)$ \\
\hline & $\begin{array}{l}\text { Vetos (plebiscito) } \\
\text { derrubados }\end{array}$ & - & 86 & 70 & - & 156 & $(39 \%)$ \\
\hline & $\begin{array}{l}\text { Leis sancionadas } \\
\text { (subtotal) }\end{array}$ & 93 & 95 & 75 & - & 263 & $(66 \%)$ \\
\hline \multirow{2}{*}{$\begin{array}{l}\text { Eleitores } \\
\text { locais }\end{array}$} & $\begin{array}{l}\text { Maioria contrária } \\
\text { (plebiscito) }\end{array}$ & 2 & 1 & 5 & - & 8 & $(2 \%)$ \\
\hline & $\begin{array}{l}\text { Maioria favorável } \\
\text { (subtotal) }\end{array}$ & 91 & 94 & 70 & - & 255 & $(64 \%)$ \\
\hline
\end{tabular}

27 Controlar as comissões (CAM e CCJ) é um requisito fundamental para os atores políticos que desejam promover ou restringir as emancipações municipais. Tanto a CAM quanto a CCJ não se limitam a verificar as tecnicalidades do processo, mas também fazem julgamentos políticos. No caso do Rio Grande do Sul, a pequena quantidade de arquivamento de solicitações emancipacionistas indica que a posição favorável à criação de municípios foi majoritária nessas comissões. No entanto, a oposição dos governadores ou o lobby contra as emancipações conseguiu, em alguns momen- tos, bloquear a criação de municípios, como demonstra o discurso do deputado Caio Riela (PTB), presidente da CAM: "Pensamos que não tivesse passado pela Comissão de Constituição e Justiça por haver voto contrário de alguns Deputados que a compõem. São necessários sete votos favoráveis. Uma série de municípios, mesmo tendo os requisitos, não foram aprovados na Comissão, talvez por ser uma decisão política, decorrente do lobby praticado [...]” (RIO GRANDE DO SUL. ASSEMBLÉIA LEGISLATIVA. COMISSÃO DE ASSUNTOS MUNICIPAIS, 2005). 


\begin{tabular}{|c|c|c|c|c|c|c|c|}
\hline \multirow{2}{*}{$\begin{array}{c}\text { Deputados } \\
\text { no Plenário } \\
\text { da } \\
\text { Assembléia } \\
\text { Legislativa }\end{array}$} & $\begin{array}{l}\text { Leis (emancipação) } \\
\text { rejeitadas } \\
\end{array}$ & - & - & - & - & & $(-)$ \\
\hline & $\begin{array}{l}\text { Leis aprovadas } \\
\text { (subtotal) }\end{array}$ & 91 & 94 & 70 & - & 255 & $(64 \%)$ \\
\hline $\begin{array}{c}\text { Poder } \\
\text { Executivo }\end{array}$ & $\begin{array}{c}\text { Leis (emancipação) } \\
\text { vetadas }\end{array}$ & 2 & 94 & 70 & - & 166 & $(42 \%)$ \\
\hline \multirow{3}{*}{$\begin{array}{c}\text { Deputados } \\
\text { no Plenário } \\
\text { da } \\
\text { Assembléia } \\
\text { Legislativa }\end{array}$} & $\begin{array}{c}\text { Vetos (emancipação) } \\
\text { aceitos } \\
\end{array}$ & 2 & - & - & - & - & $(-)$ \\
\hline & $\begin{array}{c}\text { Vetos (emancipação) } \\
\text { derrubados }\end{array}$ & - & 94 & 70 & - & 164 & $(41 \%)$ \\
\hline & $\begin{array}{l}\text { Leis sancionadas } \\
\text { (total) }\end{array}$ & $89(90 \%)$ & $94(84 \%)$ & $70(41 \%)$ & - & 253 & $(64 \%)$ \\
\hline
\end{tabular}

FONTE: Rio Grande do Sul. Assembléia Legislativa. Comissão de Assuntos Municipais (2005).

TABELA6 - TRAMITAÇÃO E RESULTADOS DO PROCESSO DECISÓRIO DAS EMANCIPAÇÕES MUNICIPAIS NO RIO GRANDE DO SUL (1953-1965)

\begin{tabular}{|c|c|c|c|c|c|c|c|}
\hline \multirow[b]{2}{*}{$\begin{array}{l}\text { Atores } \\
\text { políticos }\end{array}$} & \multirow[b]{2}{*}{ Resultado } & \multicolumn{4}{|c|}{ GOVERNADORES } & & \\
\hline & & $\begin{array}{c}(1951-1954) \\
\text { governo } \\
\text { PTB } \\
\text { (Ernesto } \\
\text { Dorneles) }\end{array}$ & $\begin{array}{c}(1955-1958) \\
\text { governo PSD } \\
\text { (Ildo Mene- } \\
\text { ghetti) }\end{array}$ & $\begin{array}{c}(1959-1962) \\
\text { Governo } \\
\text { PTB (Leonel } \\
\text { Brizola) }\end{array}$ & $\begin{array}{c}(1963-1966) \\
\text { governo } \\
\text { PSD (Ildo } \\
\text { Meneghetti) }\end{array}$ & \multicolumn{2}{|c|}{ Total } \\
\hline $\begin{array}{l}\text { Líderes } \\
\text { locais }\end{array}$ & $\begin{array}{c}\text { Pedidos protocolados } \\
\text { na Assembléia } \\
\text { Legislativa }\end{array}$ & $32(100 \%)$ & $47(100 \%)$ & & $115(100 \%)$ & 194 & $(100 \%)$ \\
\hline \multirow{5}{*}{$\begin{array}{c}\text { Deputados } \\
\text { nas } \\
\text { comissões } \\
\text { (CE e CCJ) } \\
\text { da Assem- } \\
\text { bléia } \\
\text { Legislativa }\end{array}$} & $\begin{array}{c}\text { Pedidos } \\
\text { reapresentados na } \\
\text { Assembléia } \\
\text { Legislativa } \\
\end{array}$ & - & - & $7(100 \%)^{*}$ & - & 7 & $(6 \%)$ \\
\hline & Pedidos rejeitados & 6 & 15 & & 11 & 32 & $(16 \%)$ \\
\hline & $\begin{array}{c}\text { Pela CE (Comissão } \\
\text { Especial) }\end{array}$ & 6 & & - & - & 6 & $(3 \%)$ \\
\hline & Pela CCJ & - & 15 & & 11 & 26 & $(13 \%)$ \\
\hline & $\begin{array}{l}\text { Pedidos aceitos } \\
\text { (subtotal) }\end{array}$ & 26 & 32 & 7 & 104 & 169 & $(87 \%)$ \\
\hline \multirow{2}{*}{$\begin{array}{l}\text { Deputados } \\
\text { no penário } \\
\text { da Assem- } \\
\text { bléia } \\
\text { Legislativa }\end{array}$} & $\begin{array}{l}\text { Leis (plebiscito) } \\
\text { rejeitadas }\end{array}$ & - & - & - & - & - & $(-)$ \\
\hline & $\begin{array}{l}\text { Leis aprovadas } \\
\text { (subtotal) }\end{array}$ & 26 & 32 & 7 & 104 & 169 & $(87 \%)$ \\
\hline $\begin{array}{c}\text { Poder } \\
\text { Executivo }\end{array}$ & $\begin{array}{l}\text { Leis (plebiscito) } \\
\text { vetadas }\end{array}$ & 4 & & & 17 & 21 & $(11 \%)$ \\
\hline \multirow{3}{*}{$\begin{array}{l}\text { Deputados } \\
\text { plenário da } \\
\text { Assem- } \\
\text { bléia } \\
\text { Legislativa }\end{array}$} & $\begin{array}{l}\text { Vetos (plebiscito) } \\
\text { aceitos }\end{array}$ & - & - & - & - & - & $(-)$ \\
\hline & $\begin{array}{l}\text { Vetos (plebiscito) } \\
\text { derrubados }\end{array}$ & 4 & - & - & 17 & 21 & $(11 \%)$ \\
\hline & $\begin{array}{l}\text { Leis sancionadas } \\
\text { (subtotal) }\end{array}$ & 26 & 32 & 7 & 104 & 169 & $(87 \%)$ \\
\hline \multirow{3}{*}{$\begin{array}{l}\text { Eleitores } \\
\text { Locais }\end{array}$} & $\begin{array}{l}\text { Maioria contrária } \\
\text { (plebiscito) }\end{array}$ & - & - & - & 4 & 4 & $(2 \%)$ \\
\hline & Plebiscitos suspensos & - & - & - & 17 & 17 & $(9 \%)$ \\
\hline & $\begin{array}{c}\text { Maioria favorável } \\
\text { (subtotal) }\end{array}$ & 26 & 32 & 7 & 83 & 148 & $(76 \%)$ \\
\hline
\end{tabular}




\begin{tabular}{|c|c|c|c|c|c|c|c|}
\hline \multirow{2}{*}{$\begin{array}{l}\text { Deputados } \\
\text { no Plenário } \\
\text { da Assem- } \\
\text { bléia } \\
\text { Legislativa }\end{array}$} & $\begin{array}{l}\text { Leis (emancipação) } \\
\text { rejeitadas }\end{array}$ & - & - & - & - & - & $(-)$ \\
\hline & $\begin{array}{l}\text { Leis aprovadas } \\
\text { (subtotal) }\end{array}$ & 26 & 32 & 7 & 83 & 148 & $(76 \%)$ \\
\hline \begin{tabular}{|c|} 
Poder \\
Executivo \\
\end{tabular} & $\begin{array}{l}\text { Leis (emancipação) } \\
\text { vetadas }\end{array}$ & - & - & - & 3 & 3 & $(1 \%)$ \\
\hline \multirow{3}{*}{$\begin{array}{l}\text { Deputados } \\
\text { no Plenário } \\
\text { da Assem- } \\
\text { bléia } \\
\text { Legislativa }\end{array}$} & $\begin{array}{l}\text { Vetos (emancipação) } \\
\text { aceitos } \\
\end{array}$ & - & - & - & 1 & 1 & $(0 \%)$ \\
\hline & $\begin{array}{c}\text { Vetos (emancipação) } \\
\text { derrubados }\end{array}$ & - & - & - & 2 & 2 & $(1 \%)$ \\
\hline & $\begin{array}{l}\text { Leis sancionadas } \\
\text { (total) }\end{array}$ & 26 (81\%) & $32(68 \%)$ & $7(100 \%)$ & $82(71 \%)$ & 147 & $(76 \%)$ \\
\hline
\end{tabular}

FONTE: Rio Grande do Sul. Assembléia Legislativa (2005).

NOTAS:

1. PSD: Partido Social-Democrata.

2.* A legislação estadual definia que somente em anos terminados em "3" ou "8" haveria emancipação de municípios. Entretanto, para permitir a emancipação de pedidos em tramitação na Assembléia Legislativa (reapresentados pelos deputados estaduais), no governo de Brizola foi aprovado uma lei que tornou possível a criação desses municípios no período.

3.** A Assembléia Legislativa aprovou leis de criação de municípios mesmo nos casos em que a população local foi desfavorável à emancipação em consulta plebiscitária.

Nos pedidos de emancipação que tiveram a consulta plebiscitária aprovada, raramente o eleitorado local encerrou o processo votando majoritariamente contrário à criação do novo município. Em todos os casos que o eleitorado manifestou-se favoravelmente a Assembléia Legislativa seguiu a decisão e aprovou a lei de criação dos municípios. No entanto, o Governador negou-se a sancionar centenas emancipações, mas somente dois desses vetos não foram derrubados pela maioria dos deputados estaduais. Ou seja, após a aprovação popular, raramente a maioria do poder Legislativo gaúcho deixou de confirmar a decisão plebiscitária, a despeito da oposição que o Executivo manteve em grande parte dos casos.

Entre todos os pedidos protocolados na Assembléia, a grande maioria transformou-se em lei que emancipou as localidades. Esse índice de aprovação ocorreu porque há, no processo de criação de municípios, uma determinação institucional que atribui ao poder Legislativo uma posição privilegiada. Os deputados, por meio das comissões ou do plenário, detêm o poder de veto sobre as iniciativas e deliberações de todos os outros atores políticos envolvidos: as lideranças locais, o eleitorado local e o poder Executivo estadual. As lideranças e, na imensa maioria dos casos, o eleitorado local pressionavam os parlamentares pela aprovação das leis de emancipação municipal. Somente o poder Executivo estadual, durante os anos
1990, procurou sistematicamente interromper as emancipações, por meio de vetos ou de pressão sobre os parlamentares governistas. Porém, apesar dessa oposição aberta - e contrariando as teses que sustentam a submissão do poder Legislativo ao Executivo estadual ${ }^{28}$-, os governadores tiveram pouco ou nenhum sucesso em limitar a autonomia da Assembléia Legislativa gaúcha na criação de novos municípios²9.

A capacidade de o poder Legislativo manter suas posições deriva do contexto institucional, das estratégias dos atores políticos e da forma que a interação entre os dois poderes desenvolveu-se historicamente no processo emancipacionista. Quanto mais municípios eram criados e quanto

28 Ver a "regra do situacionismo", apresentada na tese do ultrapresidencialismo estadual por Abrúcio (1998).

29 Grohmann (2000, p. 34, 41), em um estudo sobre o processo legislativo do Rio Grande do Sul (entre 1995 e 1998), descreve resultados semelhantes no relacionamento entre os poderes Executivo e Legislativo gaúchos. No entanto, o autor indica que esse tipo de autonomia legislativa dos deputados gaúchos, no período investigado, foi restrito ao processo decisório das emancipações municipais e à votação das leis orçamentárias. O autor conclui que "via de regra, os padrões de relacionamento entre executivo e legislativo" foram determinados pelo poder Executivo, devido ao "poder de agenda" desse poder e à ocorrência de "maioria absoluta e coesa" apoiando o Governador no parlamento estadual (idem, p. 44-45). 
mais derrotas a Assembléia Legislativa impunha ao poder Executivo, mais demandas pela criação de novos municípios ingressavam no Legislativo e mais fortes as lideranças emancipacionistas, a CAM e a maioria dos deputados sentiam-se para impor futuras derrotas ao poder Executivo. O processo emancipacionista gaúcho é, em grande parte, resultante da capacidade de os deputados estaduais transformarem a matéria em um tema de exclusiva deliberação popular (plebiscitária) e legislativa. A criação de municípios foi excluída da negociação fisiológica ou programática com o poder Executivo. Isso restringiu o jogo de barganhas e sanções entre os atores políticos quando a emancipação entrava na pauta parlamentar ${ }^{30}$.

No Rio Grande do Sul, a maioria dos parlamentares estaduais votou favoravelmente à criação dos municípios devido a suas expectativas eleitorais futuras. Ou seja, a maioria dos parlamentares não era indiferente a ponto de seguir a reprovação do poder Executivo estadual. Para essa maioria, negar a criação dos municípios geraria a expectativa de uma perda difusa de votos que superaria aquela imposta pelas retaliações do Executivo. Isso tornou débeis as ameaças de sanções que o Executivo fizesse aos membros de uma coalizão governista frágil e ideologicamente heterogênea. Além disso, negar a emancipação de uma localidade é muito mais do que se opor a uma lei clientelista qualquer. Devido à dimensão dos interesses locais em jogo, sofrer uma retaliação eleitoral futura seria uma expectativa racional para os parlamentares que fossem responsabilizados pelo insucesso na emancipação da localidade.

A criação das centenas de novos municípios gaúchos ocorreu devido ao apoio dos parlamentares emancipacionistas e à lógica de decisão da maioria dos deputados estaduais; ao contexto político-institucional, gaúcho e brasileiro, extremamente favorável às emancipações municipais e à incapacidade de o poder Executivo estadual impor suas preferências à maioria do parlamento, fosse por uma alteração na regulamentação estadual que restringisse a fragmentação territorial, fosse pela falta de mecanismos de sanção que coagisse, individualmente, cada deputado de sua base parlamentar a sustentar seus vetos às leis ordinárias.

\footnotetext{
30 Para uma descrição detalhada das relações ExecutivoLegislativo na criação de municípios no Rio Grande do Sul, ver Tomio (2002a) e Tomio e Canto (2003).
}

\section{CONSIDERAÇÕES FINAIS}

Dentre os 5564 municípios que compõem a República Federativa do Brasil, um total de 1385 (253 no Rio Grande do Sul) não existiam antes da promulgação da última Constituição. A intensidade da recente fragmentação das unidades de governo local, assim como a institucionalização de uma federação em três níveis, é um fenômeno político restrito ao Brasil. Essa multiplicação de governos locais não possui qualquer paralelo contemporâneo. Outros países registram somente a ocorrência de alguns eventos isolados que, diferentemente dos municípios brasileiros, geralmente possuem um grau muito limitado de autonomia.

O arranjo institucional democrático, gerado pela Constituição de 1988 e existente antes de 1964, por meio de vários mecanismos específicos, estimulou a criação de milhares de novos municípios; mais importante que isso, tornou possível que decisões favoráveis às emancipações predominassem no processo decisório estadual. Primeiramente porque a consolidação da descentralização fiscal garantiu a estabilidade das transferências fiscais aos municípios; essas transferências estimularam as populações e os líderes políticos de pequenas localidades a demandar sua emancipação política.

O segundo mecanismo que favoreceu a criação de municípios foi a regulamentação estadual das emancipações privativa aos estados. Isso ampliou drasticamente a disponibilidade de localidades emancipáveis e, portanto, a quantidade de proposições de criação de municípios que ingressavam nas assembléias, por meio de iniciativa dos deputados ou das lideranças locais.

Por último, vários mecanismos legais (federais e estaduais) instituíram uma tramitação dos pedidos de emancipação que atribuiu aos legislativos estaduais um papel preponderante no processo decisório da criação de municípios. Em alguns estados, como no Rio Grande do Sul, isso predispôs o poder Legislativo a conquistar uma autonomia maior frente ao poder Executivo. Além disso, a participação popular na proposição legislativa, a prerrogativa exclusiva de os eleitores iniciarem a tramitação do processo e a manifestação popular no plebiscito limitaram a capacidade de controle do poder Executivo sobre o resultado legislativo. Na maior parte dos casos de votação de leis de emancipação ou de derrubada de vetos do Executivo, quando teve que escolher entre so- 
frer a retaliação do eleitorado ou do Executivo, a maioria legislativa foi mais sensível à pressão dos eleitores.

Como o processo emancipacionista não cessava nos estados, tal qual no regime militar o governo federal voltou a intervir para interromper a criação de novos municípios. Sem a alteração do regime político, a recentralização das regras por meio da Emenda Constitucional n. 15/96 alterou o arranjo institucional que favorecia as emancipações. Isso só foi possível porque o poder Executivo federal vinculou a mudança constitucional à estabilidade fiscal. No entanto, como os estímulos fiscais aos eleitores locais e a lógica das expectativas eleitorais dos parlamentares estaduais não foram modificados, novas decisões favoráveis às emancipações municipais provavelmente ocorrerão após o Congresso Nacional regulamentar a Emenda n. 15/96.

Além disso, o processo de criação de municípios apresenta questões sobre o papel dos mecanismos de democracia direta (plebiscito e exclusividade na iniciativa legislativa). As consultas plebiscitárias sobre a criação de municípios, juntamente com a iniciativa popular na legislação, representam o espaço mais extenso e significativo de investigação sobre os mecanismos de democracia direta no Brasil. O estudo da fragmentação municipal brasileira poderia servir como uma abertura para novas investigações sobre a relação entre democracia direta e processo decisório, cidadania e gestão dos governos locais.

A fragmentação municipal também apresenta questões ao estudo (descritivo e normativo) das instituições políticas brasileiras: a crítica do arranjo institucional do federalismo brasileiro, o papel dos níveis de governo, os mecanismos de estímulo à cooperação e à competição entre as entidades governamentais. Nesse sentido, creio que é interessante apresentar algumas considerações sobre a fragmentação municipal e o desenho institucional brasileiro.

Afinal, criar um município é um problema ou uma solução? Obviamente, a resposta depende do ponto de vista. Para os eleitores de pequenas localidades do interior significa uma maior oferta de emprego (geralmente públicos) e oportunidade de renda. Eventualmente, até pode significar a melhoria efetiva de alguns serviços públicos. Em conjunto, isso poderia reduzir o êxodo populacional das pequenas localidades para os grandes e médios centros urbanos. Caso esses efeitos ocorressem de fato, criar municípios poderia ser visto de maneira mais pragmática do que as justificativas usuais (radicalização democrática e racionalidade na administração pública); poderia ser entendido como uma política progressiva de redistribuição de renda ou de prevenção ao inchaço dos principais centros urbanos, com um grau de ineficiência variando conforme o custo das elites políticas locais e de suas demandas futuras.

Por outro lado, quando muitos municípios são criados em poucas unidades da federação e em um tempo muito exíguo, isso gera um problema orçamentário, tanto para os níveis mais abrangentes de governo quanto para os outros municípios que não se fragmentaram e que dependem das transferências. Menos recursos nos antigos municípios e mais governantes locais com demandas legitimadas pelo status municipal (e por eleições) significam maior pressão por gastos públicos nos estados e na União. Isso parece inadmissível em um momento em que austeridade administrativa, estabilidade econômica, equilíbrio orçamentário e superávit fiscal para honrar a dívida pública são tratados enquanto compromissos inalienáveis pelo consenso político dominante.

No passado recente a criação de municípios já foi definida como problema e como solução. As instituições estimularam ou reprimiram as emancipações em uma oscilação que não variou, necessariamente, com o regime político. Em virtude disto, não me surpreenderia se em um espaço curto de tempo uma nova institucionalidade descentralizadora substituísse a hegemonia centralista atual. A despeito dessa institucionalidade ciclotímica, creio que há três aspectos relacionados à divisão municipal que parecem problemáticos no arranjo institucional do federalismo brasileiro.

O primeiro aspecto vincula-se à forma de distribuição do FPM entre os municípios. O efeito redistributivo do Fundo é transferir renda gerada nos grandes centros para as pequenas municipalidades. O resultado foi um estímulo crescente à fragmentação dos micromunicípios. Como os municípios mais populosos são menos dependentes do Fundo, os grandes perdedores nessa fórmula de distribuição foram os pequenos e médios municípios do interior, sobretudo aqueles que 
não se dividiram. Se a lógica da distribuição do FPM é populacional, a institucionalização de uma distribuição per capita acabaria com o impacto negativo das emancipações nos municípios que não se dividem e restringiria o estímulo à fragmentação dos micromunicípios.

Outro aspecto relaciona-se à instrumentalização do texto constitucional pelos objetivos políticos da coalizão de governo no nível federal (poder Executivo e maioria legislativa). Durante a década de 1990 houve um contínuo processo constituinte que, em geral, violou os princípios federativos institucionalizados no país de maneira quase similar ao regime militar. A recentralização das regras sobre a fragmentação política interna dos estados foi somente um exemplo de fragilização da federação. Por mais justas que fossem as preocupações sobre o equilíbrio fiscal, elas não justificariam a violação da autonomia dos estados. Essa foi uma solução para suspender a onda emancipacionista e eventualmente teve o apoio de alguns governadores incapazes de exercer suas preferências no processo decisório estadual. Contudo, possui sérias implicações sobre a concepção de quais limites devem ser impostos aos governantes na alteração das normas jurídicas fundamentais do Estado. Da mesma forma que é violada a federação, direitos individuais também poderiam ser alterados para atender aos objetivos pontuais dos governos.
Finalmente, há a própria forma de institucionalização dos governos locais no Brasil. Esses reúnem um alto grau de autonomia formal com uma padronização constitucional nas atribuições e prerrogativas. Pressupor que unidades de governo local (com mil ou milhões de habitantes) tenham a mesma capacidade de exercer a autonomia política, gerar recursos fiscais, administrar as demandas locais e executar políticas públicas etc., beira o absurdo. A ausência de variações na definição das funções e competências dos municípios, pela via constitucional ou por delegação dos estados, cria expectativas irrealizáveis na maior parte dos governos locais. Enquanto os pequenos municípios comportam-se mais como grupos de interesse com status público do que como organizações governamentais, as grandes municipalidades são proibidas (pelas regras institucionais) de gerir políticas que poderiam executar com maior racionalidade, eficácia e controle público do que as esferas mais abrangentes. Enfim, é possível que a maior intensidade da fragmentação municipal recente tenha contribuído para a fragilidade da estabilidade política e orçamentária. Entretanto, creio que a ausência de unidades intermediárias de governo local entre os estados e os municípios e a uniformização da estrutura e da autonomia política dos municípios devem ter uma contribuição mais incisiva para os problemas da democracia brasileira que a multiplicação de municípios.

Fabricio Ricardo de Limas Tomio (tomio@intervip.psi.br; fab_tom@hotmail.com) é Doutor em Ciências Sociais pela Universidade Estadual de Campinas (UNICAMP) e professor do Departamento de Direito Público da Universidade Federal do Paraná (UFPR).

\section{REFERÊNCIAS BIBLIOGRÁFICAS}

ABRÚCIO, F. L. 1998. Os barões da federação : os governadores e a redemocratização brasileira. São Paulo : Hucitec.

ABRÚCIO, F. L. \& SAMUELS, D. 1997. A nova política dos governadores. Lua Nova, São Paulo, n. 40-41.

AFFONSO, R. B. A. \& SILVA, P. L. B. (orgs.). 1995a. Reforma tributária e federação. São Paulo : UNESP.

1995b. A federação em perspectiva. São Paulo : FUNDAP.
ALMEIDA, M. H. T. 1995. Federalismo e políticas sociais. Revista Brasileira de Ciências Sociais, São Paulo, ano 10, n. 28.

ANDRADE, R. C. 1998. Processo de governo no município e no estado. São Paulo : USP.

ARRETCHE, M. T. S. 1995. Descentralização, democracia, reforma do Estado e bem-estar : conceitos que não se equivalem. Artigo apresentado no XIX Encontro Nacional da Associação Nacional de Pesquisa e Pós-graduação em Ciências Sociais, realizado em Caxambu (MG). Digit. 
1996. Mitos da descentralização - mais democracia e eficiência nas políticas públicas? Revista Brasileira de Ciências Sociais, São Paulo, v. 11, n. 31.

1998. O processo de descentralização das políticas sociais no Brasil e seus determinantes. Campinas. Tese (Doutorado em Ciências Sociais). Universidade Estadual de Campinas.

1999. Políticas sociais no Brasil : descentralização em um estado federativo. Revista Brasileira de Ciências Sociais, São Paulo, v. 14, n. 40, p. 111-141, jun.

ATALIBA, G. 1987. Regime federativo. In : FAORO, R. (org.). Constituição e constituinte. São Paulo : Revista dos Tribunais.

1991. Criação de município - plebiscito. Revista de Direito Público, n. 98, ano 24.

AVELINO FILHO, G. 1994. Clientelismo e política no Brasil - revisitando velhos problemas. Novos Estudos CEBRAP, São Paulo, n. 38, p. 225-240, mar.

BAÊTA, A. M. C. 1989. Administração municipal e descentralização política : notas para uma discussão. Revista de Administração Pública, Rio de Janeiro, v. 23, n. 4, p. 100-107.

BARDO, J. \& BARDO, D. 1983. A ReExamination of Subjective Components of Comunity Satisfaction in a British New Town. Journal of Social Psychology, v. 120, n. 1.

BARRETO, C. E. 1971. Constituições do Brasil. São Paulo : Saraiva.

BREMAEKER, F. E. J. 1991. Os novos municípios brasileiros instalados entre 1980 e 1990. Rio de Janeiro : Instituto Brasileiro de Administração Municipal.

1993. Os novos municípios : surgimento, problemas e solução. RAM, Rio de Janeiro, v. 40, n. 206.

1996. Limites à criação de novos municípios : a emenda constitucional n. 15. RAM, Rio de Janeiro, v. 43, n. 219.

BRIFFAULT, R. 1988. Localism in State Constitutional Law. Annals AAPSS, Philadelphia, v. 496, p. 117-127, Mar.

CAPUTO, D. A. 1975. General Revenue Sharing and American Federalism : Towards the Year
2000. Annals AAPSS, Philadelphia, v. 419, p. 130-142, May.

CASTRO, J. N. 1987. O poder regional - autonomia municipal e constituinte. Revista de Administração Pública, Rio de Janeiro, v. 21, n. 1, p. 2-9.

COLUSSI, E. L. 1996. Estado Novo e municipalismo gaúcho. Passo Fundo : UPF.

CRAVER, G. A. 1999. An Evaluation of the City of Danville-Pittsylvania County Annexation (Virginia). Richmond. Dissertação (Master of Urban and Regional Planning). Virginia Commonwealth University.

CRAWFORD, S. \& OSTROM, E. 1995. A Grammar of Institutions. American Political Science Review, Washington, D. C., v. 89, n. 3.

DAGNAUD, M. 1981. Goursolas on New Towns : A Critical Comment. International Journal of Urban and Regional Research, v. 5, n. 4.

DUCHACEK, I. D. 1988. State Constitutional Law in Comparative Perspective. Annals AAPSS, Philadelphia, v. 496, p. 128-139, Mar.

FIGUEIREDO, A. C. \& LIMONGI, F. 1994. O processo legislativo e a produção legal no congresso pós-constituinte. Novos Estudos CEBRAP, São Paulo, n. 38, p. 24-37, mar.

1995. Mudança constitucional, desempenho do legislativo e consolidação institucional. Revista Brasileira de Ciências Sociais, São Paulo, ano 10, n. 29.

1997. O Congresso e as medidas provisórias : abdicação ou delegação? Novos Estudos CEBRAP, São Paulo, n. 47, p. 127-154, mar.

1999. Executivo e Legislativo na nova ordem constitucional. Rio de Janeiro : Fundação Getúlio Vargas.

FISCHER, T. (org.). 1993. Poder local - governo e cidadania. Rio de Janeiro : Fundação Getúlio Vargas.

GIANNINI, C. M. C. 1990. Federação : a unidade na diversidade. Revista Cepam, ano 1, n. 1.

GOMES, G. M. \& MACDOWELL, M. C. 1997. Os elos frágeis da descentralização. Seminário Internacional "Federalismo e governos locais”, realizado em La Plata, Argentina. Digit. 
GOURSOLAS, J. M. \& ATLAS, M. 1980. New Towns in the Paris Metropolitan Area : An Analytic Survey of the Experience, 1965-79. International Journal of Urban and Regional Research, v. 4, n. 3.

GRAVES, T. J. 1974. IGR and the Executive Branch : The New Federalism. Annals AAPSS, Philadelphia, v. 416, p. 40-51, Nov.

GROHMANN, L. G. M. 1996. Concentração e dispersão de votos : uma contribuição ao debate brasileiro. Trabalho apresentado no XX Encontro Nacional da Associação Nacional de Pesquisa e Pós-graduação em Ciências Sociais, realizado em Caxambu (MG). Digit.

2000. O processo legislativo no Rio Grande do Sul : 1995 a 1998. Artigo apresentado no $2^{\circ}$ Encontro da Associação Brasileira de Ciência Política, realizado em São Paulo (SP). Digit.

GRUMM, J. G. \& MURPHY, R. D. 1974. Dillon's Rule Reconsidered. Annals AAPSS, Philadelphia, v. 416, p. 120-132, Nov.

HALL, P. \& TAYLOR, R. 1997. La Science Politique et les trois néo-institutionnalismes. Revue Française de Science Politique, Paris, v. 47, n. 3-4, p. 469-496, juin-aôut.

HESSEL, J. R. 1976. A criação de municípios no Rio Grande do Sul. Rio de Janeiro : Fundação Getúlio Vargas.

HILLENBRAND, B. F. 1974. Countries : The Emerging Force. Annals AAPSS, Philadelphia, v. 416, p. 91-98, Nov.

IBGE. 2005. Perfil de municípios 2002. Rio de Janeiro : Instituto Brasileiro de Geografia e Estatística. Disponível em : http:// www.ibge.gov.br/. Acesso em : 30.jun.2005.

IMMERGUT, E. 1996. The Normative Roots of the New Institutionalism : Historical Institutionalism and Comparative Policy Studies. Baden-Baden : digit.

JACOBI, P. 1990. Descentralização municipal. Revista CEPAM. São Paulo, ano 1, n. 3.

1991. Os municípios e a participação : desafios e alternativas. Revista de Administração Municipal, Rio de Janeiro, v. 38, n. 198.

KLERING, L. R. 1991. Desempenho dos novos municípios - emancipações políticas do RS na década de 80 : razões, histórico e diretrizes. In : MINCARONE, M. Emancipação : liberdade para prosperar. Porto Alegre : Assembléia Legislativa do Estado do Rio Grande do Sul.

LEVI, M. 1991. Uma lógica da mudança institucional. Dados, Rio de Janeiro, v. 34, n. 1.

LIMONGI, F. 1994. O novo institucionalismo e os estudos legislativos. BIB, São Paulo, n. 37.

LOWNDES, V. 1996. Varieties of New Institutionalism : A Critical Appraisal. Public Administration, v. 74.

MACMANUS, S. A. 1990. Financing Federal, State, and Local Governments in the 1990s. Annals AAPSS, Philadelphia, v. 509, p. 22-35, May.

MARANDO, V. L. 1973. Voting in City-County Consolidation Referenda. The Western Political Quarterly.

MEDINA, A. V. A. 1987. Tarefas ou poder : o que descentralizar? Cadernos de Pesquisa, São Paulo, n. 60, p. 45-47.

MELLO, D. L. 1991. Descentralização, papel dos governos locais no processo de desenvolvimento nacional e recursos financeiros necessários para que os governos locais possam cumprir seu papel. Revista de Administração Pública, Rio de Janeiro, v. 25, n. 4, p. 199217.

1992. A multiplicação dos municípios no Brasil. RAM, Rio de Janeiro, v. 39, n. 203.

1993. O governo municipal brasileiro : uma visão comparativa com outros países. Revista de Administração Pública, Rio de Janeiro, v. 27, n. 4, p. 36-53.

MEDINA, A. V. A. 1987. Tarefas ou poder : o que descentralizar? Cadernos de Pesquisa, São Paulo, n. 60, p. 45-47.

MELLO, D. L. 1991. Descentralização, papel dos governos locais no processo de desenvolvimento nacional e recursos financeiros necessários para que os governos locais possam cumprir seu papel. Revista de Administração Pública, Rio de Janeiro, v. 25, n. 4, p. 199217.

1992. A multiplicação dos municípios no Brasil. RAM, Rio de Janeiro, v. 39, n. 203. 
1993. O governo municipal brasileiro : uma visão comparativa com outros países. Revista de Administração Pública, Rio de Janeiro, v. 27, n. 4, p. 36-53.

MELO, M. A. B. C. 1993. Municipalismo, nation building e a modernização do Estado no Brasil. Revista Brasileira de Ciências Sociais, São Paulo, ano 8, n. 23.

MESQUITA, Z. 1992. Emancipações no RS : alguns elementos para reflexão. Análise Conjuntural, Porto Alegre, v. 20.

MINCARONE, M. 1991. Emancipação : liberdade para prosperar. Porto Alegre : Assembléia Legislativa do Rio Grande do Sul.

MONTORO, E. A. F. 1974. A organização do município na federação brasileira. São Paulo. Tese (Doutorado em Ciências Jurídicas e Sociais). Pontifícia Universidade Católica de São Paulo.

MOUW, C. J. \& MACKUEN, M. B. 1992. The Strategic Agenda in Legislative Politics. American Political Science Review, Washington, D. C. v. 86, n. 1.

NATHAN, R. P. 1975. Federalism and the Shifting Nature of Fiscal Relations. Annals AAPSS, Philadelphia, v. 419, p. 120-129, May.

NATHAN, R. P. \& LAGO, J. R. 1990. Intergovernmental Fiscal Roles and Relations. Annals AAPSS, Philadelphia, v. 509, p. 36-47, May.

ORLOFF, A. S. 1993. A Comparative Analysis of Britain, Canada, and the United States, 1880-1940. Madison : University of Wisconsin.

PAGANO, M. A. 1990. State-Local Relation in the 1990s. Annals AAPSS, Philadelphia, v. 509, p. 94-105, May.

PEEL, M. 1995. The Rise and Fall of Social Mix in an Australian New Town. Journal of Urban History, v. 22, n. 1.

RUTLEDGE, P. J. 1974. Federal-Local Relations and the Mission of the City. Annals AAPSS, Philadelphia, v. 416, p. 77-90, Nov.

SANTOS, F. G. M. 1995. Microfundamentos do clientelismo político no Brasil : 1959-1963. Dados, Rio de Janeiro, v. 38, n. 3.

2001. O poder Legislativo nos estados : diversidade e convergência. Rio de Janeiro : Fundação Getúlio Vargas.

SEYLER, W. C. 1974. Interlocal Relations : Cooperation. Annals AAPSS, Philadelphia, v. 416, p. 158-169, Nov.

SHIKIDA, C. D. 1998. Emancipação de municípios em Minas Gerais (1995) : uma abordagem novo-institucionalista e de escolha pública. São Paulo. Dissertação (Mestrado em Economia). Universidade de São Paulo.

SKABURSKIS, A. 1989. Options the Developing Resource Towns : The Effects of Increasing Government Involvement in New Town Development. Journal of Architectural and Planning Research, v. 6, n. 4.

SOARES, M. M. 1998. Federação, democracia e instituições políticas. Lua Nova, São Paulo, n. 44.

TEIXEIRA, E. 1994. Ações coletivas e poder local - um mapeamento. Cadernos do CEAS, n. 154.

1992. Cidadania e poder local. Cadernos do CEAS, n. 136.

TEUNE, H. 1995. Local Government and Democratic Political Development. Annals AAPSS, Philadelphia, v. 540, p. 11-23, July.

THELEN, K. \& STEINMO, S. 1992. Historical Institutionalism in Comparative Politics. In : STEINMO, S. (ed.). Structuring Politics : Historical Institutionalism in Comparative Analysis. Cambridge : Cambridge University.

TOBAR, F. 1991. O conceito de descentralização : usos e abusos. Planejamento e Políticas Públicas, Rio de Janeiro, n. 5.

TOMIO, F. R. L. 1998. Explosão municipal : notas de uma pesquisa. In : FLÔRES, J. R. A. \& NATIVIDADE, M. O. (orgs.). Política, cultura \& sociedade. Santa Maria : UFSM.

2002a. Instituições, processo decisório e relações Executivo-Legislativo nos estados : estudo comparativo sobre o processo de criação de municípios após a Constituição de 1988. Campinas. Tese (Doutorado em Ciências Sociais). Universidade Estadual de Campinas.

2002b. A criação de municípios após a constituição de 1988. Revista Brasileira de Ciências Sociais, São Paulo, v. 17, n. 48, p. 
61-89, fev.

TOMIO, F. R. L. \& CANTO, E. R. 2003. O processo decisório de criação de municípios no RS entre 1946 e 1964. Trabalho apresentado no XI Congresso da Sociedade Brasileira de Sociologia, realizado em Campinas (SP), de $1^{\circ}$ a 5 de setembro de 2005. Digit.

UGA, M. A. D. 1991. Descentralização e democracia : o outro lado da moeda. Planejamento e Políticas Públicas, Rio de Janeiro, n. 5.

VASOO, S. 1988. The Development of New Towns in Hong Kong and Singapore : Some Social Consequences. International Social Work, v. 31, n. 2.

VIZZOTTO, A. R. 1997. A emancipação e divisão política de Faxinal do Soturno, causas e conseqüências. Santa Maria. Dissertação (Mestrado em Ciência Política). Universidade
Federal de Santa Maria.

WRIGHT, D. S. 1974. Intergovernmental Relations : An Analytical Overview. Annals AAPSS, Philadelphia, v. 416, p. 1-16, Nov.

1975. Revenue Sharing and Structural Features of American Federalism. Annals AAPSS, Philadelphia, v. 419, p. 100-119, May.

1990. Policy Shift in the Politics and Administration of Intergovernmental Relations, 1930s-1990s. Annals AAPSS, Philadelphia, v. 509, p. 60-72, May.

ZIMMERMAN, J. F. 1974. The Metropolitan Area Problem. Annals AAPSS, Philadelphia, v. 416, p. 133-147, Nov.

1990. Regulating Intergovernmental Relations in the 1990s. Annals AAPSS, Philadelphia, v. 509, p. 48-59, May.

\section{OUTRASFONTES}

BRASIL. 1998. Constituição da República Federativa do Brasil. Brasília : Senado Federal.

BRASIL. Senado Federal. 1988. Emendas populares à Assembléia Nacional Constituinte. Brasília : Senado Federal. ral.

2005. Legislação. Brasília : Senado Fede-

FRANCE. Ministère des Affaires Étrangères. 1996. La administracion territorial. Paris : Ministère des Affaires Étrangères.

IBGE. Vários anos. Censos. Rio de Janeiro : Instituto Brasileiro de Geografia e Estatística. Disponível em : http://www.ibge.gov.br/. Acesso em : 30.jun.2005.
RIO GRANDE DO SUL. Assembléia Legislativa. 2005. Porto Alegre : Assembléia Legislativa do Rio Grande do Sul. Disponível em: http:// www.al.rs.gov.br/. Acesso em : 30.jun.2005.

RIO GRANDE DO SUL. Assembléia Legislativa. Comissão de Assuntos Municipais. 2005. Porto Alegre : Assembléia Legislativa do Rio Grande do Sul. Disponível em: http:// www.al.rs.gov.br/. Acesso em : 13.jul.2005.

UNITED STATES OF AMERICA. Bureau of the Census. 1994. Census of Governments Government Organization. Washington, D. C. : Bureau of the Census. 
Versão dos resumos para o inglês: Miriam Adelman

FEDERALISM, MUNICIPALITIES AND LEGISLATIVE DECISIONS: THE CREATION OF MUNICIPALITIES IN THE RIO GRANDE DO SUL

\section{Fabrício Ricardo de Limas Tomio}

This article approaches the process politician who generated the thousands of new municipalities in Brazil, using the state of the Rio Grande do Sul as scene of the relations between state legislative/ executive and from the second half of century XX. The recent spalling of the units of local government, as well as the institutionalization of federalism in three levels, is a phenomenon restricted politician to Brazil. Between the states, the Rio Grande do Sul was that one that more intensely broke up its territory. It enters the years of 1988 and 2000 had been created 253 new municipalities in this state. To describe this process I will use an historical-institutional approach. The decisions favorable to the creation of municipalities had predominated in the state power to decide process: 1 ) because the consolidation of the fiscal decentralization guaranteed the stability of the fiscal transferences to the municipalities; 2) the decentralization of the a regulation of the new municipalities to the states; 3 ) legislative the state ones had conquered great autonomy in the power to decide process of the creation of municipalities, as in the Rio Grande do Sul, where the popular participation in the legislative proposal, the exclusive prerogative of the voters to initiate the transaction of the process and the popular manifestation in the plebiscite, had limited the capacity of control of the executive on the legislative result.

KEYWORDS: federalism; State Legislative; new towns. 
Versão dos resumos para o francês: Maria Fernanda Araújo Lisboa FÉDÉRALISME, VILLES ET DÉCISIONS LÉGISLATIVES: LACRÉATION DE VILLES DANS LE RIO GRANDE DO SUL

Fabrício Ricardo de Limas Tomio

Cet article porte sur le processus politique qui a créé des milliers de nouvelles villes au Brésil et utilise l'état brésilien de Rio Grande do Sul comme cadre des relations entre les pouvoirs exécutif et législatif locaux à partir de la deuxième moitié du XX ${ }^{\text {ème }}$ siècle. La nouvelle segmentation des unités du gouvernement régional ainsi que l'institutionalisation d'une fédération à trois niveaux, c'est un phénomène politique particulier au Brésil. Parmi les états qui le constituent, Rio Grande do Sul fut celui qui a fragmenté davantage son territoire : entre les années 1988 et 2000, on a créé 253 nouvelles villes dans cet état. Pour décrire ce processus, j’utiliserai l'approche historico-institutionnelle. Les décisions favorables à la création de villes l'emportèrent au long de la prise de décision sur le plan régional : 1) parce que la consolidation de la décentralisation fiscale assura la stabilité des transferts fiscaux aux villes; 2) en fonction de la décentralisation de la réglémentation des nouvelles villes en faveur des états et 3 ) parce que les pouvoirs législatifs locaux conquirent une immense autonomie au moment de décider pour la création de villes, comme dans l'état de Rio Grande do Sul, où la participation populaire à la proposition législative, la prérogative qui autorisait les électeurs à initier la démarche de ce processus et la manisfestation populaire au plébiscite limitèrent la capacité de contrôle du pouvoir exécutif sur le résultat législatif.

MOTS-CLES: fédéralisme; pouvoir législatif régional; nouvelles villes. 